\title{
Implementation Strategies of Higher Education Part of National Education Policy 2020 of India towards Achieving its Objectives
}

\author{
P. S. Aithal* \& Shubhrajyotsna Aithal** \\ *College of Management \& Commerce, Srinivas University, Mangalore - 575 001, INDIA \\ OrcidID: 0000-0002-4691-8736; E-mail: psaithal@gmail.com \\ **Faculty, College of Engineering \& Technology, Srinivas University, Mangalore, India \\ OrcidID: 0000-0003-1081-5820; E-mail: shubhraaithal@gmail.com
}

Area/Section: Business Management.

Type of the Paper: Explorative Research.

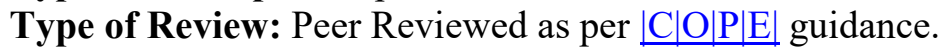

Indexed in: OpenAIRE.

DOI: http://doi.org/10.5281/zenodo.4301906

Google Scholar Citation: IJMTS.

\section{How to Cite this Paper:}

Aithal, P. S. \& Aithal, Shubhrajyotsna (2020). Implementation Strategies of Higher Education Part of National Education Policy 2020 of India towards Achieving its Objectives. International Journal of Management, Technology, and Social Sciences (IJMTS), 5(2), 283325. DOI: http://doi.org/10.5281/zenodo.4301906.

International Journal of Management, Technology, and Social Sciences (IJMTS) A Refereed International Journal of Srinivas University, India.

(C) With Author.

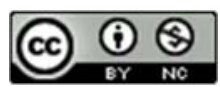

This work is licensed under a Creative Commons Attribution-Non-Commercial 4.0 International License subject to proper citation to the publication source of the work.

Disclaimer: The scholarly papers as reviewed and published by the Srinivas Publications (S.P.), India are the views and opinions of their respective authors and are not the views or opinions of the SP. The SP disclaims of any harm or loss caused due to the published content to any party. 


\title{
Implementation Strategies of Higher Education Part of National Education Policy 2020 of India towards Achieving its Objectives
}

\author{
P. S. Aithal* \& Shubhrajyotsna Aithal** \\ *College of Management \& Commerce, Srinivas University, Mangalore - 575 001, INDIA \\ OrcidID: 0000-0002-4691-8736; E-mail: psaithal@gmail.com \\ **Faculty, College of Engineering \& Technology, Srinivas University, Mangalore, India \\ OrcidID: 0000-0003-1081-5820; E-mail: shubhraaithal@gmail.com
}

\begin{abstract}
Well defined and futuristic education policy is essential for a country at school and college levels due to the reason that education leads to economic and social progress. India with the leadership of its current prime minister and an expert team with members of varied backgrounds has developed and planned to implement a new education policy during the next decade of the $21^{\text {st }}$ century called Indian National Education Policy (NEP-2020). The aim, objectives, and details are well known to practitioners and the public. NEP-2020 is an innovative and futuristic proposal with both positive and negative aspects, framed with the objective to provide a quality school education and higher education to everyone with an expectation of holistic \& research-oriented progress. This paper initially depicts an overview of NEP-2020, distinguish the strengths \& weakness of the policy at higher education $\&$ research part, evaluation of the implementation suggestions given in the policy, identifying and analyzing possible generic strategies for implementation of NEP-2020 to fulfill its objectives based on focus group discussions. The paper also includes many predictive proposals on issues like developing quality universities \& colleges, institutional restructuring \& consolidation, more holistic \& multidisciplinary education, optimal learning environment \& student support, transforming the regulatory system of higher education, technology usage \& integration, and online \& digital education. Finally, some recommendations are made to implement the NEP2020 effectively irrespective of various constraints. This article can be considered as a reference to the policy implementation teams of Govt of India.
\end{abstract}

Keywords: NEP 2020, Indian Higher Education Policy, Implementation Strategies, Indian Higher Education System, Research and innovation focus.

\section{INTRODUCTION :}

Being the first education policy of the 21st century, National Educational Policy (NEP-2020) India has a challenge and hence goal to lift the country as a developed country by supporting developmental imperatives according to 4th goal of United Nations Sustainable Development Goals (SDGs), which aims to "ensure inclusive and equitable quality education and promote lifelong learning opportunities for all" by 2030. India believes that through this new national education policy 2020, it can achieve this goal at least by 2040 with equitable access to high-quality education to everyone irrespective of social and economic background.

With the vision of creating a platform to provide quality school \& higher education to every citizen of the country with Indian ethos and values to transform the country as an equitable and vibrant knowledge society and global knowledge superpower by improving the quality of education at every stage by creating a new ideal system through the revision and revamping the current education structure including, policies, regulations, and control systems, the new policy NEP-2020 is designed [1-2]. Thus, it is expected that the new policy NEP-2020 is a thorough revision with less content but more skills for problem solving, creativity for innovation, multidisciplinary and holistic for unity and integrity. The policy expects a new set of regulations to make the education pedagogy more experimental, inquiry- 
driven, discovery-oriented learner-centered, analysis-based, flexible, enjoyable, and futuristic so that the educated output can support countries economic growth, social justice and equality, scientific advancement, cultural preservation, and national integration.

In this paper, based on an overview of NEP-2020, we have distinguished the strengths \& weakness of the policy at higher education \& research part, evaluating the implementation suggestions given in the policy, identifying and analyzing possible generic strategies for implementation of NEP-2020 to fulfill its objectives based on focus group discussions. The paper also includes many predictive proposals on issues like developing quality universities and colleges, institutional restructuring \& consolidation, more holistic \& multidisciplinary education, optimal learning environment \& student support, transforming the regulatory system of higher education, technology usage and integration, and online $\&$ digital education. Finally, we have made some recommendations to implement the NEP-2020 effectively irrespective of various constraints.

\section{RELATED WORK :}

The previous education policies of the Government of India in 1986 and modified in 1992 are failed to provide education to every citizen of the country and found inadequate in offering high quality education even if an amendment in NEP- 1986/92 was brought during 2009 with a supplementary "Right of Children to Free and Compulsory Education Act 2009" that laid down legal underpinning for achieving universal elementary education. In 2019, Govt. of India formed a committee headed by Dr. K. Kasturirangan former chairman of the Indian Space Research Organization (ISRO). The committee submitted its report in the form of a draft Education policy in December 2019 and suggested both incremental and radical changes in the existing Indian education policy with appropriate guidelines for effective implementation in the country by 2030. After a thorough investigation and 360-degree feedback-based review, the Govt of India accepted its modified version [1] in the Union Ministry meeting as National Education Policy 2020. The declaration was made by Union Ministers for Information and Broadcasting (I\&B) Prakash Javadekar and Human Resource Development (HRD) and Ramesh Pokhriyal Nishank for acceptance of the National Education Policy (NEP-2020) on Wednesday 29th July 2020.

The National Education Policy -2020 envisions an India centred education system that contributes directly to transforming our nation sustainably into an equitable and vibrant knowledge society by providing high quality education to all. It draws inputs and disciplines from the vast amount of India's heritage. The countries education system contributed many scholars including Charaka and Susruta, Aryabhata, Bhaskaracharya, Chanakya, Patanjali, and Panini, and many others. Through such eminent people, the country made seminal contributions to world knowledge in varied fields such as mathematics, astronomy, metallurgy, civil engineering and architecture, shipbuilding and navigation, medical science and surgery, yoga, fine arts, chess. The entire Indian education system is founded and built with such background, support, and inspiration. The objective of the policy is to provide a multidisciplinary and interdisciplinary liberal education to everybody based on a proposed system.

In July 2019, Aithal P. S. et al published a paper on "Analysis of Higher Education in Indian National Education Policy Proposal 2019 and Its Implementation Challenges" which reviewed the related literature during the last few years on Indian Higher Education Policies and their consequences, salient features, and their focuses on the draft of National Education policy 2019 through content analysis. The paper highlighted various policies proposed in the draft with the special emphasis on the higher education section and compared them with the previous policies. The analysis also compared the possible effects of NEP 2019 proposal on private and public HEIs in terms of facilities \& restrictions. The strength and weaknesses of the new policy proposal are identified with respect to various stakeholders and listed. The paper also contains some suggestions to realize the policy and make it defect free and effective from a public point of reference and for the prosperity of the country [2].

In August 2020, Sunil Kumar et al highlighted a new instructional procedure to see huge movements in schools and advanced edification. He has pointed the void between vision and mission would require 
more than the action plans and the strategy for execution. Therefore, it takes the right measures to ensure that implementation meets expectations [3].

In August 2020, Aithal, P. S. et al further published a paper on "Analysis of the Indian National Education Policy 2020 toward Achieving its Objectives" and highlighted various policies announced in the higher education system and compared them with the currently adopted system. Various innovations and predicted implications of NEP 2020 on the Indian higher education system along with its merits are discussed. Some suggestions are proposed for its effective implementation towards achieving its objectives [4].

Jha, P. et al (2020) commented on shortcomings of the National Education Policy, approved by the union cabinet on 29 July 2020 . NEP-2020 is the third educational policy document of the country, coming after a gap of 34 years since the last one. The article highlighted some of the relevant concerns about the question of provisioning for good quality universal education, equitable access to education, and increasing push toward privatization [5].

Suryavanshi, S. (2020) has made an attempt to compare teacher education in Indian universities with that in Chinese university as a case study and concluded that autonomy is essential to faculty members and institutional leaders to innovate and explore in their teaching, research, and service. The paper also suggested that the universities must have the individual autonomy -as proposed by NEP-2020 is definitely the right step ahead [6].

Kumar, K., et al (2020) discussed how National Education Policy 2020 can be a lodestar to transform future generations in India. They mentioned that NEP-2020 provides a comprehensive framework from primary education to higher education, vocational \& technical education, and a new paradigm of internet-based e-leanings. They identified the five founding pillars as access, equity, affordability, accountability, and quality to fulfill the UN sustainable development goal. They provided insights into various contours of NEP 2020 with caution to achieve the objectives and presented some major loopholes and execution challenges that need to be addressed for fostering quality education for all [7].

Deb, P. (2020) published an article on "Vision for Foreign Universities in the National Education Policy 2020: A Critique" that deals with the internationalization of Indian higher education as one of the stated aims of the National Education Policy (NEP) 2020 [8].

\section{OBJECTIVES OF THE STUDY :}

The current study determines various strategies to implement the NEP-2020 systematically by identifying various constraints associated with the implementation process. This includes the following specific objectives:

(1) To prepare an overview of NEP-2020.

(2) To distinguish the strengths \& weaknesses of the Policy at Higher education \& Research Part.

(3) To evaluate the implementation suggestions.

(4) To identify and analyze possible strategies for implementation of NEP-2020 to fulfill its objectives.

(5) To propose strategies to develop Quality Universities and Colleges.

(6) To propose strategies for Institutional Restructuring \& Consolidation.

(7) To propose strategies for more Holistic \& Multidisciplinary education.

(8) To propose strategies for Optimal Learning Environment \& Student Support.

(9) To propose strategies for transforming the regulatory system of HE.

(10) To propose strategies for technology use and integration.

(11) To propose strategies for online \& digital education.

(12) To provide suggestions to all stakeholders for effective implementation of the policy as per the given timeframe.

\section{OVERVIEW OF NEP-2020 :}

The National Education Policy-2020 envisions an India centred education system by incorporating its tradition, culture, values, and ethos to transform the country into an equitable, sustainable, and vibrant 
knowledge society. The NEP-2020 is developed by considering the wide and deep historical heritage of the country and the contributions of many scholars to different subjects as the founding stone to build high quality multi-disciplinary liberal education at both school and higher \& professional education level. With the objective to increase the gross enrollment ratio (GER) of school education enrollment and higher \& professional education enrollment to increase from $28 \%$ and $05 \%$ to $50 \%$ and $20 \%$ respectively by 2030 , by means of radical changes in the existing education policies and governance systems by introducing accountability in each stakeholder.

Table 1 : Various educational stages to be implemented according to NEP 2020 [1]

\begin{tabular}{|c|c|c|}
\hline S. No. & $\begin{array}{l}\text { Educational life-cycle } \\
\text { Stage }\end{array}$ & Features \\
\hline 1 & $\begin{array}{l}\text { Foundation Stage } \\
\text { (Five-year duration) }\end{array}$ & $\begin{array}{l}\text { The foundation stage intends to give basic education to children } \\
\text { between age } 3 \text { to } 8 \text { years with play-based and activity-based } \\
\text { learning for cognitive, mental, and emotional development. }\end{array}$ \\
\hline 2 & $\begin{array}{l}\text { Preparatory Stage } \\
\text { (Three-year duration) }\end{array}$ & $\begin{array}{l}\text { The preparatory stage intends to educate children of } 9 \text { to } 11 \text { years } \\
\text { with activity-based and discovery-based learning by introducing } \\
\text { different subjects in a systematic classroom setup along with } \\
\text { textbooks to support deeper insights. }\end{array}$ \\
\hline 3 & $\begin{array}{l}\text { Middle school } \\
\text { education Stage }\end{array}$ & $\begin{array}{l}\text { Middle school education intends to provide a more abstract } \\
\text { concept in various subjects through a liberal education model } \\
\text { with a focus on experimental learning. There will be two class } \\
\text { level exams annually (semester-based system). }\end{array}$ \\
\hline 4 & $\begin{array}{l}\text { Secondary education } \\
\text { Stage } \\
\text { (Four-year duration) }\end{array}$ & $\begin{array}{l}\text { The focus in secondary school education is multidisciplinary } \\
\text { subjects with flexible exit options to prepare them for the next } \\
\text { level of specialized undergraduate programmes. The pedagogy } \\
\text { of courses in this stage will be built with increased depth and } \\
\text { flexibility according to student choice. Attention will be given to } \\
\text { life aspirations while offering the subject groups. The semester } \\
\text { system will be followed in this stage with } 5 \text { to } 6 \text { subjects in each } \\
\text { semester and common board exams will be conducted at the end } \\
\text { of } 10^{\text {th }} \text { and } 12^{\text {th }} \text { standards. }\end{array}$ \\
\hline 5 & $\begin{array}{l}\text { Under-graduation } \\
\text { Education Stage } \\
\text { (Three to four-year } \\
\text { duration) }\end{array}$ & $\begin{array}{l}\text { The undergraduate higher education stage consists of four } \\
\text { optional exits: a certificate after one year, a diploma after the } \\
\text { second year, bachelor's degree after the third year, and an } \\
\text { honours degree after the four years with options of major, } \\
\text { minors, and research projects. }\end{array}$ \\
\hline 6 & $\begin{array}{l}\text { Post-graduation } \\
\text { Education Stage } \\
\text { (One to two-year } \\
\text { duration) }\end{array}$ & $\begin{array}{l}\text { The Masters degree is re-defined as (i) One-year duration } \\
\text { programme for four years honours bachelor's degree students, } \\
\text { (ii) Two-years programme for three years bachelor's degree } \\
\text { students, and (iii) five years integrated degree programme for } \\
12^{\text {th }} \text { standard pass students. The Masters degree will have a } \\
\text { research focus to strengthen competence in a professional } \\
\text { domain, specifically on high quality research in the final year to } \\
\text { prepare students for the next research degree. }\end{array}$ \\
\hline
\end{tabular}




\begin{tabular}{|l|l|l|}
\hline 7 & Research Stage & $\begin{array}{l}\text { Though research is an integral part of the final year } \\
\text { undergraduate and postgraduate stages, the research scholars at } \\
\text { (Three to Four-year } \\
\text { duration) } \\
\text { Ph.D. in any core, multidisciplinary, or interdisciplinary areas } \\
\text { for a minimum period of 3 years for full-time and 4 years for } \\
\text { part-time, respectively. During Ph.D. they should undergo } \\
\text { minimum 8-credit coursework in teaching/education/pedagogy } \\
\text { related to their chosen Ph.D. subject. No MPhil programme will } \\
\text { be offered as a research degree. }\end{array}$ \\
\hline 8 & Lifelong learning & $\begin{array}{l}\text { As lifelong learning is essential for every human being in } \\
\text { society, the NEP 2020 also proposes lifelong learning and } \\
\text { research to avoid the obsolesce of human beings in society in } \\
\text { terms of knowledge, skills, and experience leading to confidence } \\
\text { based comfortable life. It is believed that education and research } \\
\text { at any stage of life will give further maturity for satisfaction and } \\
\text { enlightenment in life. }\end{array}$ \\
\hline
\end{tabular}

\subsection{School Education :}

With the key principles of (i) respect for diversity \& local context, (ii) Equity \& inclusion, (iii) Community participation, (iv) Emphasizing conceptual understanding, (v) Building unique capabilities, (vi) Imparting critical thinking and creativity, (vii) Use of Technology, and (viii) continuous review, NEP-2020 has intended to focus on universal access to early child care \& education. This is to be done through foundational learning curriculum, multifaceted learning models, and preparatory classes at the childhood level. Ensuring universal access to education at all levels, school education emphasizes multiple pathways, bringing back drop-outs, promoting on building schools, promoting alternative and innovative education centres, achieving desired outcomes, and peer tutoring at all levels to ensure access and opportunities to all children [4]. The salient features of school education as depicted in NEP-2020 are:

(1) The early childhood education will focus on - Developing curiosity, Teamwork and collaboration, Logical thinking and problem solving, Play-based and discovery-based learning, Arts, crafts, \& music, Ethics, Relationship with nature, Self-identity, Colours, Shapes, Alphabets and numbers, Etiquette, Behaviour, and Emotional development. The emphasis is on the reduction in the curriculum with core essentials, critical thinking, interactive classes, and experimental learning.

(2) The school education as per NEP-2020 focuses on competency-based education, integration of subjects, and development of scientific temper. There is no hard separation between subjects and learning by giving equal importance to all professions, emphasis on digital literacy, and multilingual teaching. NEP-2020 also emphasizes on acquiring skills in health and nutrition, physical education, fitness, wellness, and sports as a mandatory requirement in school education.

(3) The innovations in school education and curriculum, including the preparation of textbooks with local content and flavour, and contents with a focus on STEAM (Science, Technology, Engineering, Arts \& design, Mathematics) model.

(4) Examination system focuses on the assessment of core concepts and knowledge, higher order skills and its applications in real life situations, avoiding rote learning, testing on achievements of essential learning outcomes. The school results will only be used for quality improvement and school developmental purposes and not for comparing students and their intelligence. There will be a census assessment at key stages 3,5 , and 8 to keep track of achievement. 
(5) Reforming exams at grade 9 to 12 by making them easier to test primarily the core competencies by incorporating a test model with both objective type and descriptive type questions.

(6) Standards, norms, and guidelines of school education are supported and monitored by PARAKH National centre.

(7) Assessment culture will be innovated by (i) Continuous tracking, (ii) Board exam based assessment of essential skills, which involves core concepts, foundational and higher order skills, (iii) Use of Artificial Intelligence (AI) based software to track student progress and career counselling, (iv) Self and peer assessment with the help of National Assessment Centre, and (v) High quality common aptitude test through centralized National Testing Agency (NTA).

(8) NEP-2020 also proposes a multidimensional holistic progress card with 360-degree assessment scores included from self-assessment, peer assessment, and teacher assessment on project-based and inquiry-based learning, quizzes, role plays, group work, portfolios, etc. to reflect the progress uniqueness of learners in the cognitive, affective, socio-emotional, and psychomotor.

(9) NEP-2020 also encourages multi-language learning with local language instructions compulsorily up to $5^{\text {th }}$ standard and preferably up to $8^{\text {th }}$ standard.

(10) Schools are restructured as school complexes/clusters with Bal Bhavan and Samajik Chethna Kendras to promote social, intellectual, and voluntary activities. Pairing-schools concept will be introduced by pairing one government school with one private school across the country for sharing resources and improving efficiency.

(11) Improving the quality through standard setting and accreditation process to all schools by means of self-disclosure of all basic regulatory information as per the regulatory body named School Quality Assessment and Accreditation Framework (SQAAF).

(12) The teacher qualification required is also standardized to a minimum B.Ed. qualification to teach from the foundation stage to middle school education and Master's degree in multidisciplinary along with one-year M.Ed. to Secondary education stage. B.Ed. programme is redesigned as One-year B.Ed. for Master's degree holders, Two-year B.Ed. for Bachelor's degree holders, and 4-year Integrated B.Ed. for $12^{\text {th }}$ pass students.

(13) Other important issues pertaining to equity for socially and economically weaker, physically disabled sections, and children with special needs in school education through various strategies to reduce category wise gaps.

(14) Integrating vocational education at all levels, special support for gifted/balanced students to pursue beyond general school curriculum through special project clubs, Olympiads, and competitions, encouraging extensive use of technology to identify and develop hidden talents are other aspects of the policy.

(15) Quality of school education will be monitored by means of (i) State School Standards Authority (SSSA), (ii) Compulsory self-disclosure in school website, and (iii) Assessment and accreditation of all public and private schools periodically by developing school quality assessment and accreditation framework (SQAAF).

\subsection{Higher Education :}

The highlights of NEP-2020 for higher education section [1], [2], [4] are listed below:

(1) Higher education (HE) monitoring and controlling institutions like UGC, AICTE, MCI, DCI, INC, etc will be merged with the Higher Education Commission of India (HECI) as a single regulator for HEIs. 
(2) The current Accreditation Institutions such as NAAC and NAB will be replaced by a robust National Accreditation Council (NAC).

(3) Establishment of a National Research Foundation (NRF) to fund research in universities and colleges.

(4) Consolidation of existing fragmented HEIs into two types of Multidisciplinary Universities (MU) and Multidisciplinary Autonomous Colleges (AC) with the campus having more than 3,000 students. The Timeline to become multi-disciplinary is by 2030 and have to be grown more than 3,000 students campus by 2040 .

(5) Multidisciplinary Universities will be of two types as (1) Research-intensive Universities, and (2) Teaching-intensive Universities.

(6) Every existing College will develop into either degree granting autonomous College or migrated into a Constituent College of University and becomes fully a part of the University.

(7) The Gross Enrolment Ratio in HE, including Vocational education will be increased from the current $26.3 \%$ (2018) to $50 \%$ by 2035 .

(8) HEIs, which deliver the highest quality will get more incentives from the government.

(9) All existing affiliated Colleges will eventually grow autonomous degree-granting colleges with the mentoring support of affiliated universities by improving and securing the prescribed accreditation level.

(10) The nomenclature of HEIs in the country such as 'deemed to be university', 'affiliating university', 'affiliating technical university', 'unitary university' will be replaced simply by 'University' on fulfilling the criteria as per norms.

(11) Research will be included in UG, PG level, and have a holistic and multidisciplinary education approach.

(12) Pedagogy in HEIs will focus on an increased emphasis on communication, discussion, debate, research, and opportunities for cross-disciplinary and interdisciplinary thinking.

(13) An Academic Bank of Credit (ABC) will be established, which would digitally store the academic credits earned from various recognized HEIs (SWAYAM \& ODL mode) so that the degrees from an HEI can be awarded taking into account credits earned.

(14) Four-year Bachelor's degree with multiple exit options, one to two-year Master's degree based on the number of years spent in Bachelor's degree as four or three, respectively, and option to do Ph.D. for four-year Bachelor's degree with research are possible.

(15) The post-graduate education will be reshaped with Two-year Master's degree with full research in the second year, One-year Master's degree for four-year Bachelor's degree holders, and Five-year integrated Bachelor's/Master's degree.

(16) All HEIs will focus on research and innovation by setting up (1) Start-up incubation centres, (2) Technology development centres, (3) Centres in frontier areas of research, (4) Centre for Industryacademic linkage, and (5) Interdisciplinary Research Centres including humanities and social science research.

(17) Student centred teaching \& learning process will be implemented instead of current teacher centred teaching model.

(18) Choice Based Credit System is revised by an innovative and flexible Competency Based Credit System.

(19) Examination system will change from high-stakes examinations (Semester End system) towards a more continuous and comprehensive evaluation examination system.

(20) All HEIs will have professional academic and career counselling centres with counsellors available to all students to ensure physical, psychological, and emotional well-being.

(21) All HEIs will develop, support, and fund for topic-centred clubs and activities organized by students with the help of faculty and other experts as needed in the area of science, mathematics, poetry, language, literature, debate, music, sports, etc.

(22) Encouragement will be made for Online Distance Learning (ODL) courses as part of degree programmes to include the credit system.

(23) The Degree programmes may contain in-class teaching, Online teaching components, and ODL components with 40:30:30 ratio model to achieve a global standard of quality.

(24) HE quality will be improved to a global quality level to attract more international students and the credits acquired in foreign universities will be counted for the award of a degree. 
(25) National Scholarship Portal will be strengthened and expanded to help the financial needs of meritbased students. Private HEIs will be encouraged to offer larger numbers of free ships and scholarships to their students.

\subsection{Teachers Education :}

The highlights of NEP-2020 for teacher's education part of higher education section [1], [2], [4] are listed below:

(26) All stand-alone Teachers Education Institutions should convert themselves as Multi-disciplinary HETs by 2030 to offer only four-year integrated B.Ed. programme.

(27) All schools of foundation, preparatory, middle, and secondary level should appoint 4-year integrated B.Ed. degree holders as teachers with dual major specializations (Education \& Subject).

(28) Till 2030, there will be two years B.Ed. programme for 3-year UG and one-year B.Ed. for fouryear UG and those who have Master's degree in other subjects.

(29) M.Ed. will be one-year with a research focus. The faculty profile in Departments of Education will be diverse with Ph.D.'s in different areas.

(30) All interested senior or retired faculty will be utilized for short or long term for guiding, mentoring, or professional support for research/training/innovation. A separate National Mission for Mentoring will be established.

\subsection{Professional Education :}

The highlights of NEP-2020 for the professional education of higher education section [1], [2], [4] are listed below:

(31) All stand-alone institutions in any field shall aim to become multidisciplinary institutions offering holistic and multidisciplinary education by 2030 .

(32) HEIs will be encouraged to prepare professionals in agriculture and veterinary sciences through programmes integrated with general education. Institutions offering agricultural education must focus on the local community directly and will get support to set up Agricultural Technology Parks to promote technology incubation and dissemination.

(33) Universities/institutions offering law education must prefer to offer bilingual education for future lawyers and judges - in English and in the language of the State.

(34) Healthcare education system must be integrated in such a way that all students of allopathic medical education must have a basic understanding of Ayurveda, Yoga and Naturopathy, Unani, Siddha, and Homeopathy (AYUSH), and vice versa. There must be greater emphasis on preventive healthcare and community medicine in all forms of healthcare education.

(35) Technical education should be offered within multidisciplinary education institutions and should focus on opportunities to engage deeply with other disciplines. The focus should be on offering Artificial Intelligence (AI), 3-D machining, big data analysis, and machine learning, in addition to genomic studies, biotechnology, nanotechnology, neuroscience, with applications to health, environment, and sustainable living.

\subsection{Private Institutions :}

The highlights of NEP-2020 for private institutions of higher education section [1], [2], [4] are listed below:

(36) All private universities are eligible for graded autonomy based on their accreditation status.

(37) All private universities/autonomous colleges must maintain an openness in their financial dealings and the BoG is responsible for any irregularities in the accounting system. BoG should contain eminent people well reputed in their professional area to guide the speedy development of the HEIs.

(38) All HEIs have autonomy in deciding their fee structure and surplus, if any, should be reinvested in the expansion projects with a transparent accounting system.

(39) All private HEIs should offer 20\% free-ship and 30\% scholarship in the course fee for meritorious students in every course which they offer during a given academic year and this should be checked and confirmed by the accreditation process.

(40) National Research Foundation will treat all private HEIs on par with public HEIs for granting research funds which is based only on the merit of the proposals. 
(41) Private institutions which cannot expand and emerge as multidisciplinary with less than 3,000 student's strength will eventually close down.

\section{EXPECTED CONSEQUENCES OF NEP-2020 ON HIGHER EDUCATION INSTITUTIONS:}

As per the present regulations of NEP-2020, the following consequences are expected for the next 10 years :

(1) Small government colleges that do not have land and other infrastructure and cannot emerge as autonomous degree granting colleges due to a small number of students (below 3,000) are eventually either close down or merge with their affiliating public university [4] as shown in figure 1.

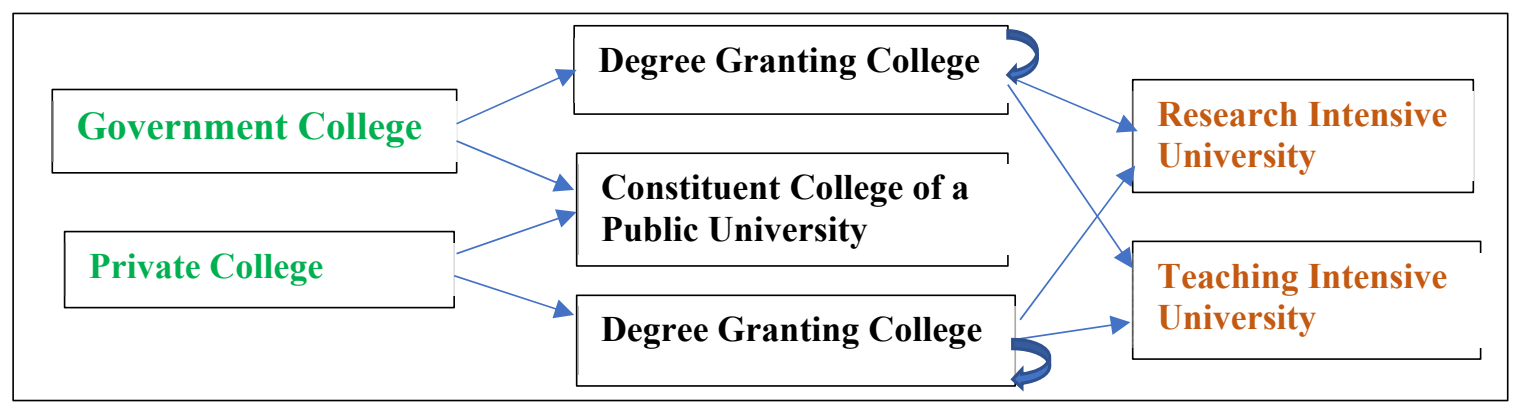

Fig.1 : Life-cycle of affiliated colleges after NEP-2020 implementation

Table 2: Fate of various higher education institutions during the implementation of NEP-2020

\begin{tabular}{|l|l|l|l|}
\hline S. No & Phase 1 & Phase 2 & Phase 3 \\
\hline 1 & $\begin{array}{l}\text { Government affiliated } \\
\text { College }\end{array}$ & $\begin{array}{l}\text { Government Degree Granting } \\
\text { College }\end{array}$ & $\begin{array}{l}\text { Government Degree } \\
\text { Granting College }\end{array}$ \\
\hline 2 & Government affiliated & $\begin{array}{l}\text { Government Degree Granting } \\
\text { College }\end{array}$ & $\begin{array}{l}\text { Teaching Intensive } \\
\text { University }\end{array}$ \\
\hline 3 & $\begin{array}{l}\text { Government affiliated } \\
\text { College }\end{array}$ & $\begin{array}{l}\text { Government Degree Granting } \\
\text { College }\end{array}$ & $\begin{array}{l}\text { Research Intensive } \\
\text { University }\end{array}$ \\
\hline 4 & $\begin{array}{l}\text { Government affiliated } \\
\text { College }\end{array}$ & $\begin{array}{l}\text { Constituent college of } \\
\text { affiliated university }\end{array}$ & $\begin{array}{l}\text { Constituent college of } \\
\text { affiliated university }\end{array}$ \\
\hline 5 & Private Affiliated College & $\begin{array}{l}\text { Private degree Granting } \\
\text { College }\end{array}$ & $\begin{array}{l}\text { Private degree Granting } \\
\text { College }\end{array}$ \\
\hline 7 & Private Affiliated College & $\begin{array}{l}\text { Private degree Granting } \\
\text { College }\end{array}$ & $\begin{array}{l}\text { Teaching Intensive } \\
\text { University }\end{array}$ \\
\hline 8 & Private Affiliated College & $\begin{array}{l}\text { Forms cluster with other } \\
\text { private colleges in a given }\end{array}$ & $\begin{array}{l}\text { Private degree Granting } \\
\text { College/University }\end{array}$ \\
\hline arivate Affiliated College & $\begin{array}{l}\text { Constituent college of } \\
\text { College }\end{array}$ & $\begin{array}{l}\text { Constituent college of } \\
\text { affiliated university }\end{array}$ \\
\hline
\end{tabular}




\begin{tabular}{|l|l|l|l|}
\hline & & $\begin{array}{l}\text { region and becomes degree } \\
\text { granting college }\end{array}$ & \\
\hline 10 & Private Affiliated College & $\begin{array}{l}\text { With a lack of expansion space } \\
\text { and collaboration opportunity } \\
\text { will be phased out }\end{array}$ & Museum \\
\hline
\end{tabular}

(2) Small private colleges that do not have land and other infrastructure and cannot emerge as autonomous degree granting colleges due to a small number of students (below 3,000) are eventually either close down or become part of a private colleges cluster to give degrees through the cluster. This is due to the fact that private colleges are usually reluctant to become the constituent colleges of a public university by losing their ownership [4].

(3) The main constraint for the existing colleges to grow as multidisciplinary autonomous degree granting colleges in the urban area is the land problem. Based on modifications in existing regulations of new Regulating authorities, if multi-store buildings are allowed and the colleges are supported by low-cost long-term loan, this problem can be minimized.

(4) The essential infrastructure required for a college to emerge as an autonomous multi-disciplinary college or/and further multi-disciplinary university are (i) Physical infrastructure, (ii) Digital infrastructure, (iii) Innovative academic (Teaching-learning-evaluation) infrastructure, (iv) Intellectual property infrastructure, (v) Emotional infrastructure, and (vi) Network (industry \& alumni) infrastructure [9]. The higher education institutions which foresee and focus on improving these infrastructures can quickly grow on the ladder and can reach the level of quality HEIs.

(5) Since the competition increases in HE space due to the addition of 100 or more top ranked foreign universities, there will be enhanced investments from Indian institutions also which forces to emerge low cost -high quality universities. Such multidisciplinary research universities will eventually put pressure on autonomous degree granting colleges to improve the quality of education but by decreasing the cost of education service to the students.

(6) Research focus in NEP-2020 leads to increased IPR. The policy highlights the importance of research at undergraduate level and postgraduate level apart from research degree levels. Introducing compulsory research components at fourth year of undergraduate level and at second year postgraduate level forces the student's teams to develop new knowledge, new interpretation of existing knowledge, new products, new industrial processes, etc giving rise to IPRs in the form of scholarly publications, copyrights, and patents.

(7) Adding research components in UG and PG leads to the compulsion of a Research degree for the faculty members and consequently, Ph.D. will be an essential qualification for all College and University Teachers. This leads to an enhanced size of research community in the country and is in turn increases the IPR of the country.

(8) $20 \%$ of free seats $(100 \%$ of fee waiver) based only on the merit of the candidates in all private universities and private institutions leads to the migration of the best talents in the country to private sector education.

(9) There will be heavy competition between Public sector universities, Private sector universities, and Foreign universities in India leading to quality improvement, enhanced research contribution \& IPR, and cost reduction/heavy scholarship attractions to both Indian and foreign students which in turn improves GER of higher education in the country. 
(10) Continuous quality measures through self-declaration and light and tight regulations through redesigned NAC accreditation scores compulsorily for every two years and NIRF based quality assessment in different areas of higher education every year creates higher alertness of quality and openness of information in Higher education industry in the country.

(11) The pedagogy will be radically improved with an emphasis on intercommunication, discussion, debate, research-based cross and interdisciplinary thinking.

(12) Students can differentiate them as fast learner with other peers by studying more courses in different disciplines simultaneously and such credentials can be deposited in a digital repository called Academic Bank of Credit (ABC). The digital credits earned from different HEIs can be clubbed to get a degree.

(13) All undergraduate courses are stretched to 4 years and in $4^{\text {th }}$ year students have the opportunity to do research projects in their specialized field. This in turn increases the employability and entrepreneurability skills of the graduates.

Table 3 predicts the consequence of the effective implementation of national education policy 2020 by comparing various issues of the higher education sector based on the current scenario and future expectations.

Table 3 : Comparison of current scenario \& future expectations in Indian Higher Education Sector

\begin{tabular}{|l|l|l|l|}
\hline $\begin{array}{l}\text { S. } \\
\text { No. }\end{array}$ & Issue & Current Scenario & Future Expectation \\
\hline 1 & Institution & $\begin{array}{l}\text { Majority are Stand-alone, } \\
\text { single discipline small } \\
\text { institutions }\end{array}$ & $\begin{array}{l}\text { Large multi-disciplinary } \\
\text { autonomous institutions } \\
\text { /Universities/Clusters }\end{array}$ \\
\hline 2 & Campus Size & Few hundred students & Few thousand students \\
\hline 3 & Govt. Colleges & $\begin{array}{l}\text { Independent affiliated } \\
\text { colleges }\end{array}$ & $\begin{array}{l}\text { Constitutional Colleges of } \\
\text { previously affiliating Public } \\
\text { University }\end{array}$ \\
\hline 4 & Higher education focus & Knowledge \& skills & $\begin{array}{l}\text { Confidence through knowledge, } \\
\text { skills, experience, values \& } \\
\text { research }\end{array}$ \\
\hline 5 & Academic curriculum & Common curriculum & Customized curriculum \\
\hline 6 & Curriculum Structure & STEM & STEAM \\
\hline 7 & Industry experience & Industry visit & Compulsory Internship \\
\hline 8 & Evaluation & Choice based credit system & $\begin{array}{l}\text { Competency based evaluation } \\
\text { system }\end{array}$ \\
\hline 9 & Examination & $\begin{array}{l}\text { Focus on Semester/Year end } \\
\text { exams }\end{array}$ & Focus on continuous evaluation \\
\hline
\end{tabular}




\begin{tabular}{|c|c|c|c|}
\hline 10 & $\begin{array}{l}\text { Teaching \& Learning } \\
\text { process }\end{array}$ & Classroom based & $\begin{array}{l}\text { Classroom, Online, and } \\
\text { Industry blended }\end{array}$ \\
\hline 11 & Outcome focus & Employability & Entrepreneurability \\
\hline 12 & Marks card & $\begin{array}{l}\text { Paper based with tampering } \\
\text { possibility }\end{array}$ & $\begin{array}{l}\text { Digital with blockchain } \\
\text { technology supported security }\end{array}$ \\
\hline 13 & $\begin{array}{l}\text { Institutional \& Faculty } \\
\text { autonomy for deciding } \\
\text { Courses, Subject \& } \\
\text { Curriculum }\end{array}$ & Low or Not at all & $\begin{array}{l}\text { High level of autonomy for } \\
\text { Courses, Subject \& Curriculum }\end{array}$ \\
\hline 14 & Regulation & $\begin{array}{l}\text { Strong but Loose with } \\
\text { corruption oriented }\end{array}$ & Light but Tight \\
\hline 15 & $\begin{array}{l}\text { Online education and } \\
\text { Open Distance Learning } \\
\text { (ODL) }\end{array}$ & $\begin{array}{l}\text { Only a few universities are } \\
\text { currently allowed }\end{array}$ & $\begin{array}{l}\text { All universities who can } \\
\text { maintain quality \& financial } \\
\text { independence are allowed }\end{array}$ \\
\hline 16 & Research Model & Single discipline focussed & $\begin{array}{l}\text { Multidisciplinary, cross- } \\
\text { disciplinary \& interdisciplinary } \\
\text { focussed }\end{array}$ \\
\hline 17 & $\begin{array}{l}\text { Offer of Research } \\
\text { Funding }\end{array}$ & $\begin{array}{l}\text { Fragmented, Corrupted \& } \\
\text { less monitored }\end{array}$ & $\begin{array}{l}\text { Single funding \& monitoring } \\
\text { agency with non-corrupted } \\
\text { officers }\end{array}$ \\
\hline 18 & Institutional Leadership & $\begin{array}{l}\text { Non-meritorious but based } \\
\text { on lobbies \& partialities }\end{array}$ & $\begin{array}{l}\text { Meritorious and proven } \\
\text { recorded Role-models }\end{array}$ \\
\hline 19 & $\begin{array}{l}\text { Faculty eligibility at } \\
\text { Colleges \& Universities }\end{array}$ & $\begin{array}{l}\text { Masters Degree with } \\
\text { NET/SLET qualified }\end{array}$ & $\begin{array}{l}\text { Compulsory Ph.D. degree in a } \\
\text { relevant or related field }\end{array}$ \\
\hline 20 & $\begin{array}{l}\text { Faculty Appointment \& } \\
\text { Promotion }\end{array}$ & $\begin{array}{l}\text { Based on Reservation \& } \\
\text { Political Influence }\end{array}$ & $\begin{array}{l}\text { Meritorious and based on } \\
\text { Annual Performance Indicator } \\
\text { Scores }\end{array}$ \\
\hline 21 & $\begin{array}{l}\text { Teaching - Learning } \\
\text { Pedagogy }\end{array}$ & Faculty Centred & Student Centred \\
\hline 22 & $\begin{array}{l}\text { Institutional growth life- } \\
\text { cycle }\end{array}$ & $\begin{array}{l}\text { Most of the cases continue as } \\
\text { affiliated college life long } \\
\text { and, in few cases may } \\
\text { become autonomous } \\
\text { affiliated college }\end{array}$ & $\begin{array}{l}\text { Colleges eventually evolve as } \\
\text { Autonomous degree granting } \\
\text { colleges and then research } \\
\text { intensive or teaching intensive } \\
\text { Universities }\end{array}$ \\
\hline 23 & Faculty Accountability & Only Teaching & $\begin{array}{l}\text { Teaching, Research \& } \\
\text { Publications }\end{array}$ \\
\hline
\end{tabular}




\begin{tabular}{|c|c|c|c|}
\hline 24 & $\begin{array}{l}\text { Gross Enrollment Ratio } \\
\text { (GER) in Higher } \\
\text { Education }\end{array}$ & $26.3 \%$ in 2018 & $50 \%$ by 2035 \\
\hline 25 & Types of Universities & $\begin{array}{l}\text { Deemed to be university, } \\
\text { Affiliating university, } \\
\text { Affiliating technical } \\
\text { university, and Unitary } \\
\text { university }\end{array}$ & $\begin{array}{l}\text { University - after fulfilling the } \\
\text { criteria as per norms }\end{array}$ \\
\hline 26 & $\begin{array}{l}\text { Entry qualification for } \\
\text { Ph.D. program }\end{array}$ & $\begin{array}{l}\text { Masters degree in respective } \\
\text { areas }\end{array}$ & $\begin{array}{l}\text { Four-year Bachelor's degree } \\
\text { with research or Master's } \\
\text { degree in any area }\end{array}$ \\
\hline 27 & Research Degrees & $\begin{array}{l}\text { M.Phil., Ph.D., and other } \\
\text { higher degrees }\end{array}$ & Only Ph.D. degree \\
\hline 28 & Nature of Library & Physical Library & $\begin{array}{l}\text { Digital Library which is } \\
\text { ubiquitous }\end{array}$ \\
\hline 29 & $\begin{array}{l}\text { Monitoring Student } \\
\text { progression }\end{array}$ & $\begin{array}{l}\text { Programmed Academic } \\
\text { Management Software }\end{array}$ & $\begin{array}{l}\text { Artificial Intelligence based } \\
\text { Academic Management } \\
\text { Software }\end{array}$ \\
\hline 30 & $\begin{array}{l}\text { Internationalization of } \\
\text { Higher education }\end{array}$ & $\begin{array}{l}\text { No competition from foreign } \\
\text { universities in the country }\end{array}$ & $\begin{array}{l}\text { Competition between Indian } \\
\text { universities and top } 100 \text { foreign } \\
\text { universities within the country }\end{array}$ \\
\hline 31 & $\begin{array}{l}\text { Free Education for } \\
\text { Meritorious Students in } \\
\text { Private Institutions \& } \\
\text { Universities }\end{array}$ & $\begin{array}{l}\text { No compulsory free } \\
\text { education for Meritorious } \\
\text { Students through free-ships }\end{array}$ & $\begin{array}{l}20 \% \text { compulsory free education } \\
\text { for Meritorious Students in each } \\
\text { course }\end{array}$ \\
\hline 32 & NAC Accreditation & Once for 5 years & Once for 2 years \\
\hline 33 & $\begin{array}{l}\text { Credit Transfer Facility } \\
\text { between Indian \& } \\
\text { Foreign Universities }\end{array}$ & Not allowed & $\begin{array}{l}\text { Credits acquired in selected } \\
\text { foreign universities will be } \\
\text { permitted to count the award of } \\
\text { the degree }\end{array}$ \\
\hline 34 & $\begin{array}{l}\text { Use of technology } \\
\text { platform }\end{array}$ & $\begin{array}{l}\text { Not compulsory for students } \\
\text { and teachers }\end{array}$ & $\begin{array}{l}\text { SWAYAM based online FDP } \\
\text { training for teachers and two } \\
\text { subjects per semesters for } \\
\text { students is mandatory }\end{array}$ \\
\hline 35 & Dual degree programme & Not permitted & Permitted \\
\hline 36 & $\begin{array}{l}\text { Number of Higher } \\
\text { education Institutions }\end{array}$ & Less in rural areas & $\begin{array}{l}\text { Established in underserved } \\
\text { regions }\end{array}$ \\
\hline
\end{tabular}




\begin{tabular}{|c|c|c|c|}
\hline 37 & Government Funding & Less funding and low growth & $\begin{array}{l}\text { High funding to have } \\
\text { accelerated growth }\end{array}$ \\
\hline 38 & Affiliated colleges & Many affiliated colleges & No affiliated colleges after 2035 \\
\hline 39 & $\begin{array}{l}\text { Model of Higher } \\
\text { Education }\end{array}$ & $\begin{array}{l}\text { No integration of } \\
\text { professional and vocational } \\
\text { education }\end{array}$ & $\begin{array}{l}\text { Integrated professional \& } \\
\text { vocational education }\end{array}$ \\
\hline 40 & Accreditation Process & $\begin{array}{l}\text { Not transparent and partly } \\
\text { controlled by few } \\
\text { International publishers }\end{array}$ & $\begin{array}{l}\text { More transparent and the } \\
\text { control of International } \\
\text { publishers will vanish due to } \\
\text { focus on open access } \\
\text { publication }\end{array}$ \\
\hline 41 & $\begin{array}{l}\text { Post-Doctoral Research } \\
\text { degrees }\end{array}$ & $\begin{array}{l}\text { D.Sc., D.Litt., LLD., are } \\
\text { available currently in many } \\
\text { universities }\end{array}$ & $\begin{array}{l}\text { No post-doctoral research } \\
\text { degrees are proposed but } \\
\text { essential }\end{array}$ \\
\hline 42 & Seed Research Funding & $\begin{array}{l}\text { No annual seed fund for all } \\
\text { universities irrespective of } \\
\text { public or private type }\end{array}$ & $\begin{array}{l}\text { Annual seed fund for all } \\
\text { universities irrespective of } \\
\text { public or private type }\end{array}$ \\
\hline 43 & $\begin{array}{l}\text { Use of Technology in } \\
\text { Education training }\end{array}$ & $\begin{array}{l}\text { No concrete plan and } \\
\text { systematic process of } \\
\text { implementation }\end{array}$ & $\begin{array}{l}\text { Planning and implementation of } \\
\text { educational technology through } \\
\text { an autonomous body called } \\
\text { National Education Technology } \\
\text { Forum (NETF) }\end{array}$ \\
\hline 44 & $\begin{array}{l}\text { Use of disruptive } \\
\text { technologies in } \\
\text { Education }\end{array}$ & $\begin{array}{l}\text { No focus on use of disruptive } \\
\text { technologies like AI \& VR in } \\
\text { education training }\end{array}$ & $\begin{array}{l}\text { Special funding will be given } \\
\text { for research in the use of AI \& } \\
\text { VR in education training } \\
\text { through NRF support }\end{array}$ \\
\hline 45 & $\begin{array}{l}\text { Online teaching } \\
\text { platform and tools }\end{array}$ & $\begin{array}{l}\text { No low cost indigenised } \\
\text { online teaching platform and } \\
\text { tools are available }\end{array}$ & $\begin{array}{l}\text { Government supported low cost } \\
\text { indigenised Online teaching } \\
\text { platform and tools are available }\end{array}$ \\
\hline 46 & E-learning platforms & $\begin{array}{l}\text { Low interactive platforms } \\
\text { like DIKSHA/SWAYAM are } \\
\text { available }\end{array}$ & $\begin{array}{l}\text { High interactive platforms with } \\
\text { virtual \& augmented reality labs } \\
\text { for simulation of every } \\
\text { experiment are available }\end{array}$ \\
\hline 47 & $\begin{array}{l}\text { Annual evaluation } \\
\text { norms for Professors \& } \\
\text { Vice Chancellors }\end{array}$ & $\begin{array}{l}\text { No evaluation norms after } \\
\text { reaching professor \& Vice } \\
\text { chancellor cadre for annual } \\
\text { increment. }\end{array}$ & $\begin{array}{l}\text { Strict self-declared evaluation } \\
\text { annually with at least two } \\
\text { scholarly publications as first } \\
\text { author or five scholarly } \\
\text { publications in a team to } \\
\text { eligible for annual increment }\end{array}$ \\
\hline
\end{tabular}




\begin{tabular}{|c|c|c|c|}
\hline 48 & $\begin{array}{l}\text { Openness in Research } \\
\text { Performance Evaluation }\end{array}$ & $\begin{array}{l}\text { No compulsory norms to } \\
\text { showcase the annual research } \\
\text { output of individuals who } \\
\text { serve in public or private } \\
\text { HEIs }\end{array}$ & $\begin{array}{l}\text { Every individual faculty } \\
\text { member at all cadre level } \\
\text { should display their annual IPR, } \\
\text { citations, and H-index in } \\
\text { Google scholar/SSRN/ } \\
\text { Researchgate/ Scopus }\end{array}$ \\
\hline 49 & $\begin{array}{l}\text { Research responsibilities } \\
\text { of Administrators who } \\
\text { had academic cadre and } \\
\text { background }\end{array}$ & $\begin{array}{l}\text { Usually no research } \\
\text { involvement or evaluation } \\
\text { for annual increment and } \\
\text { continuation }\end{array}$ & $\begin{array}{l}\text { Compulsory research } \\
\text { involvement and annual } \\
\text { performance evaluation for } \\
\text { increment and continuation }\end{array}$ \\
\hline 50 & $\begin{array}{l}\text { Use of retired professors } \\
\text { as part-time Research } \\
\text { professors to guide } \\
\text { Ph.D. scholars with a } \\
\text { small monthly } \\
\text { remuneration }\end{array}$ & No norms available & $\begin{array}{l}\text { Retired professors can be } \\
\text { appointed as a part-time } \\
\text { research professor with nominal } \\
\text { monthly remuneration to guide } \\
\text { Ph.D. students irrespective of } \\
\text { their age }\end{array}$ \\
\hline 51 & $\begin{array}{l}\text { IPR takeaway along } \\
\text { with graduation or } \\
\text { postgraduation } \\
\text { certificate }\end{array}$ & $\begin{array}{l}\text { No IPR takeaway along with } \\
\text { graduation or postgraduation } \\
\text { certificate }\end{array}$ & $\begin{array}{l}\text { Every student of four years } \\
\text { graduation or two years } \\
\text { postgraduation will takeaway at } \\
\text { least one Copyright of scholarly } \\
\text { publication or Patent }\end{array}$ \\
\hline
\end{tabular}

\section{STRENGTHS \& WEAKNESS OF THE POLICY AT HIGHER EDUCATION \& RESEARCH PART OF NEP-2020 :}

The strength and weakness of the NEP act 2020 are identified from its structure and implementation point of views $[2,10]$ and are listed below :

\subsection{Strengths of the NEP-2020 Act :}

Some of the strength of Indian National Education Policy 2020 are identified and listed below [2, 4]:

(1) The NEP-2020 is futuristic and expected to fill the gap between the current status of national innovativeness and the desired state of national innovativeness.

(2) The draft contains a comprehensive proposal on all aspects of education for all levels of the people.

(3) Systematic education for children is proposed from the $3^{\text {rd }}$ year of their age.

(4) Emphasis is on manpower development, entrepreneurability, and employability.

(5) The entire proposal is based on the concept of education for equality.

(6) Private HEIs will prosper due to full autonomy for admission, choosing the curriculum, freedom in teacher's appointment without the need of following reservation policy, research funds support, and ability to retain only performers through accountability models.

(7) Private HIEs will get the freedom of admission whereas Public HEIs admit students through NEA ranking \& counselling.

(8) All types of HEIs will be multidisciplinary, accredited, and autonomous degree granting institutions at undergraduate and postgraduate levels.

(9) Mark scored by each student in each subject is based on the continuous evaluation by the concerned faculty members of the department so that the performance grade of the student will be based on true academic scores not based on his/her fate or luck.

(10) Well written by considering all aspects of education and all levels of people in society.

(11) The experience and thoughts of many experts are embedded in the Proposal. 
(12) Supports to fulfill the United Nations Sustainable development goals by 2030 .

(13) Addressed the systematic education requirement for the citizen for lifelong learning.

(14) Free education with the liberal concept along with breakfast and lunch makes education as means not punishment in the initial stage of the lifecycle.

(15) Liberalization in choosing the subjects in school and college education allows for all-round development with innovating abilities and critical \& design thinking.

(16) The policy of $20 \%$ free education and $30 \%$ subsidized education in private HEIs will give opportunities for availing free education lifelong for brilliant students.

(17) Autonomy is given to Type 3 HEIs to decide their curriculum may lead to contemporary education as per industry requirement.

(18) The proposal is innovative and supportive to break the silos of the existing system.

(19) Multiple entries and multiple exits in the under-graduate system allow students to redefine their career path based on their interest and external opportunities.

(20) Quality of B.Ed. will improve due to the fact that only type 1, and type 2 HEIs are able to offer teacher education and is the basic qualification required to all levels of school education.

(21) Digitization of the libraries leads to online information on any subject for students and faculty in support of the liberal education model.

(22) Intensive research in every subject is supported at undergraduate, post-graduate, and research levels through extensive funding support to all HEIs by National Research Foundation.

(23) Teachers are made as to the centre of the system and the measures are proposed for continuous improvement of both quality and performance of the teachers.

(24) Autonomy is given to teachers both for innovations in curriculum and innovations in evaluation methods.

(25) Students have the liberty to choose subjects both from specialization areas and across many multidisciplinary subject areas.

(26) Priority is given to research based customized education at all levels by involving both students and faculties.

(27) A compulsory social engagement for each student equal to at least a full one semester course across the duration of an undergraduate programme so that every student is exposed to the problems of the underprivileged and learns a sort of social responsibility in their life.

(28) Drastic improvement in the quality \& exposure of school teachers by making four years integrated B.Ed. as a minimum qualification for them.

(29) Opportunities to provide ODL mode of offering degree programmes for all accredited HEIs.

(30) The objective of providing education to all and higher education GER to at least $50 \%$ from the current $28 \%$ by 2030 .

(31) The proposed student faculty ratio in the schools and colleges is increased from 20:1 to 30:1 and this liberalization allows HEIs to use more industry experts (field practitioners) for part time experience sharing.

(32) Encouragement for HEIs to involve in foreign university collaboration for twining programmes, dual degree programmes, student exchange programmes, faculty exchange programmes, international research collaborations, starting off-shore campuses by Indian universities, etc.

(33) Liberal education based on STEAM (Science, Technology, Engineering, Arts \& design, and Mathematics) model is proposed from the school education to the college education system.

(34) 360-degree feedback-based faculty evaluation is given importance to assess the contribution to teaching, research, and practice.

(35) Further encouragement for research is provided by proposing a policy for National research foundation to retain IPR with the researchers.

(36) At school education level, providing free and compulsory quality pre-primary education, primary education, and secondary education for all 3-18 years children through RTE Act.

(37) Multiple regulatory bodies are merged into a single regulatory body to remove the corruption by agencies and lobbying by HEIs. Light but tight regulations are suggested.

(38) The research fund proposed for NRF (Rs. 20,000 crores) is substantially impressive and may contribute enhanced research output in all important areas of human development.

(39) Secondary stage of school education comprises of four years with eight semesters so that repeated board exams at the state level are eliminated. 
(40) All private HEIs will be treated equally with public institutions for research funding so that researchers will get equal importance and encouragement for their research contributions irrespective of the type of institution they work.

\subsection{Weakness of the NEP-2020 Act :}

Some of the weakness of Indian National Education Policy 2020 are identified and listed below [2, 4]:

(1) The subject identification and specialization into science, commerce, arts in order to choose the type of professional education are not clear.

(2) Implementation details at school levels and college levels are also not clear.

(3) The three years exit with a degree and four years exit with a research project-based degree is also confusing to get a government job under a similar degree qualification.

(4) One year and two years Masters degree programmes are also suggested and it is not clear that under what circumstances these different duration Master degree programmes have to be offered.

(5) Online Distance Learning (ODL) permission should be restricted to only universities instead of autonomous colleges too.

(6) Less importance and information is given for diploma programmes under higher education.

(7) No substantial support to improve the quality for contributing to global ranking.

(8) Accumulating required land and infrastructure for affiliated colleges to be transformed into multidisciplinary autonomous colleges is a major constraint.

(9) If all types of HEIs start offering ODL programmes the system will become worse due to unhealthy competitions.

(10) Since top class foreign universities are allowed to enter and offer educational services in India with huge investments, sustainability for Indian organizations becomes a challenge.

(11) Encouragement \& motivation for lifelong research by suggesting Post-doctoral degrees is not visible.

(12) No strong \& effective suggestion on faculty performance measurement is included for determining accountability.

(13) Promotion of open system leads to ignoring of proprietary software and proprietary knowledge.

(14) Regulatory policies may support lobbying \& corruption.

(15) The vision statement is India centric and not reflecting global relevance.

(16) The transition from the current system to the proposed future system is not progressive but disruptive.

(17) Autonomy should be earned by the HEIs based on their quality and not to be given forcefully by the government.

(18) Removing affiliated colleges leads to chaos and confusion.

(19) The proposed binary accreditation system leads to no incentives for the achievers except graded autonomy.

(20) Proposed compulsory one semester equivalent social engagement in the form of the internship is difficult for certain professional programmes.

(21) Specific procedure to increase patent filing and scholarly publications in the country is not suggested apart from encouragement for research based on enhanced funding.

\section{IMPLEMENTATION STRATEGIES :}

\subsection{Strategies Revisited :}

A strategy is a set of plans with short-cuts to ensure success in a given task. Implementation task of NEP-2020 with its planned objectives of $100 \%$ literacy and GER of more than $50 \%$ to higher education in a country like India with about 130 crores citizen with regional, religion, economic, and cultural diversity is not an easy task. Thus, the implementation of NEP-2020 needs various strategies to develop action plans to realize various objectives with expected success.

Strategic management is a vast subject that provides various ideas, concepts, strategies to ensure organizational and individual success. Though, as a subject, strategic management is initially developed to support business decisions in organizations, they are also extended to handling other types of challenges in the society to increase the gain or to decrease the loss. Some of the generic strategies used in business organizations are classified as survival strategy or black ocean strategy [11], sustainable 
strategy or green ocean strategy [12], monopoly strategy or blue ocean strategy [13], competitive strategy or red ocean strategy [14] and growth \& prosperous strategy or white ocean mixed strategy [15]. However, implementation strategies for NEP-2020 are slightly different than business strategies based on their objectives and constraints. Some of the implementation strategies include time-bound strategy [16], alternative strategy [17], project management strategy [18], accountability-based performance (Theory A) [19], Assignment strategy based on operation research, technology-based automation strategy [20], etc. Successful implementation of National Education policy in a country can be divided into various implementation strategies under strategies for its stakeholders.

\subsection{Strategies of Stakeholders :}

The stakeholders of the implementation process of National Education policy of a country include government, universities, colleges, faculty members, students, aspirants, and parents/citizen of the country. Top-Down approach is suitable because the implementation of new education policy is government oriented, government directed, government controlled, involved heavy planning elements, and government monitored. Success or failure of time bound implementation is government responsibility because it takes credit/debit for effective/ineffective implementation.

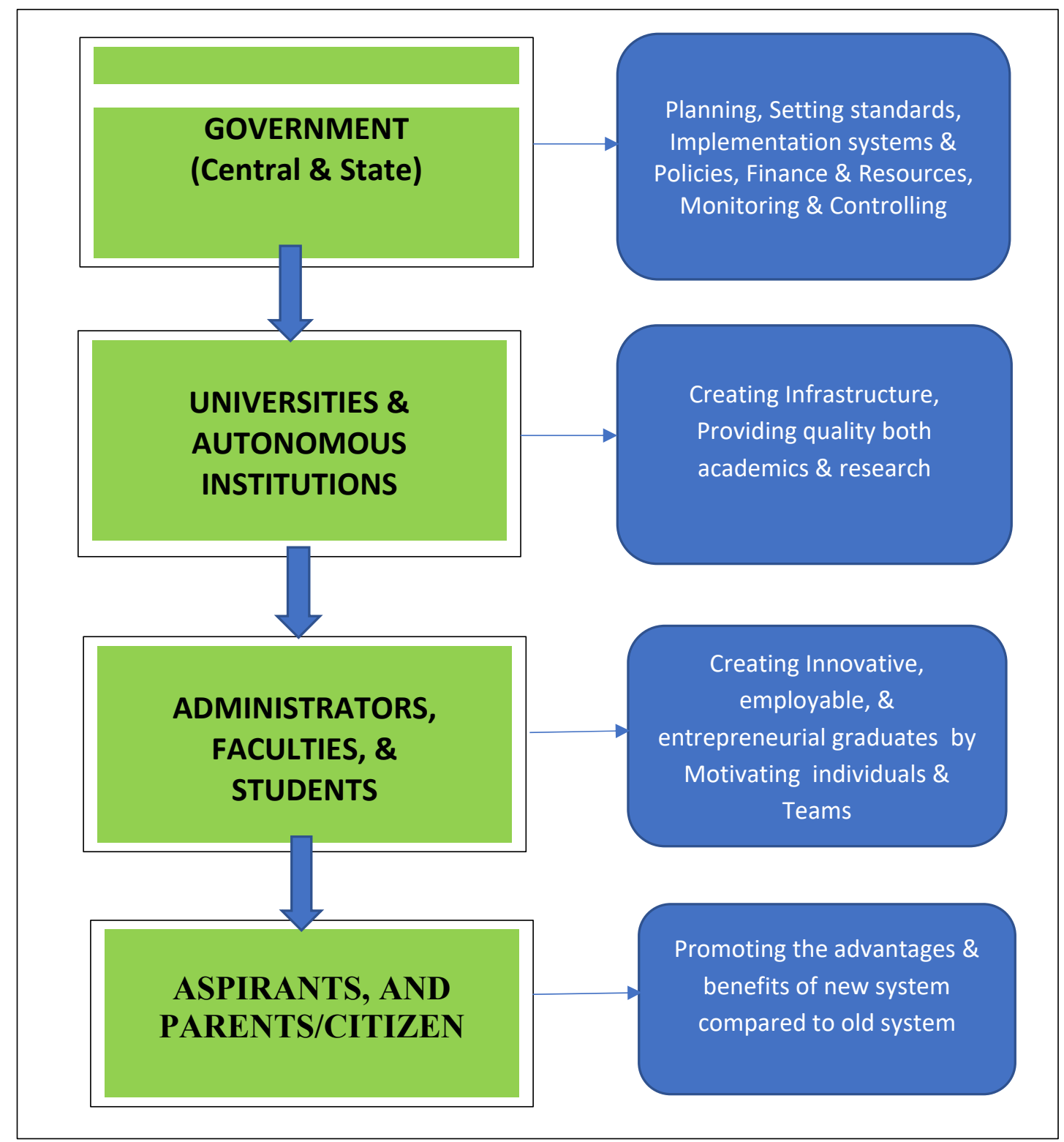

Fig. 2: Top-down implementation approach of the National Education Policy 


\subsubsection{Indian Government Strategy :}

The central government should follow an innovative leadership strategy to constitute various high-level committees with competent leadership. As per the proposal mentioned in NEP-2020, central government also follows a light but tight regulatory strategy to control the quality and competency of students graduating from these HEIs in terms of their innovability, entrepreneurability, and employability. This also includes:

(1) Improving the GER from current undergraduate education from $28 \%$ to $50 \%$ and postgraduate education from $4 \%$ to $20 \%$ by (a) lowering the unit education cost from student's point of view and increasing the number of quality higher education institutions as per anticipated demand [21].

(2) Innovativeness of the country mostly depends on access to quality higher education to the citizens of the country. When more people are involved in the research, more new ideas and new knowledge will be created which directly contributes to the innovativeness of the country. Thus, the central government, through its policies to create awareness on higher education and research should create an environment for enhancing the innovativeness of the country.

(3) Decreasing the government investment cost of higher education by means of supporting privatization of higher education and ensuring that only not-for-profit organizations establish private universities and private education institutions.

(4) Increasing the percentage of seats for free education and subsidized education from private institutions and universities. The central government should ensure that $20 \%$ of the seats in each course is offered free for meritorious students and $30 \%$ of students in each course should get $50 \%$ scholarship. Alternately, the government can ensure that all students who get admission to higher education programmes will get education loans from banks without interest.

(5) Improving the quality of higher education through standardization of light but tight regulations to all higher education offering institutions and universities.

(6) Creating world-class digital infrastructure with integrated digital content under a single National digital library with the objective of one nation-one library with availability all books and journals of all subject areas in electronic form for all citizens/members of the country.

(7) Developing and providing one or more e-learning platforms, online teaching platforms to all educational institutions of the country free of cost to maintain high quality, high technology facilities for every student of the country through NETF.

(8) Providing merit-based scholarships \& education loans to every aspiring student to pursue higher education irrespective of their religion, caste, social background, and economic background. Such education loans can be recovered at a later stage once they start earning without any annual interest. Here scholarship should be given to only to the students scored distinction marks in previous exams and education loan with no interest should be offered to every eligible candidate.

(9) Through suitable policies, creating a competitive atmosphere between government, private, and foreign universities and institutions to improve the efficiencies and effectiveness of higher education institutions towards nation building.

(10) It is known that the quality of higher education is compromised by reservation policy in different names while appointing and promoting faculty members and administrators of the universities, institutions, and regulatory bodies. NEP-2020 has not spoken in such reservation system but stressed on single criteria of performance-based appointments \& promotions. Government must adhere to this suggestion both at the appointment level and promotion level. Strict policies should be strategically developed, implemented, and monitored at all levels. For example, the appointment of Vice-chancellors to central universities and Directors to Education \& Research institutions should have norms of the minimum annual contribution to IPR (copyright/patents) individually as a role model. 
(11) The central government directions should be in such a way that the NRF fund allocation should be based on the importance of an innovative research proposal than the institutional background of the applicant.

(12) To increase in annual budget allocation from $4.6 \%$ of GDP to $6 \%$ of GDP, the central government invest more from public funds for which a separate education cess can be imposed on direct and indirect taxpayers.

(13) Based on proper expert analysis, the wastage of money spent on higher education \& research should be reduced. For example, (i) repetition of research facilities \& imported instruments in the same research institution under different research professors, and nearby institutions in a district/state, should be eliminated through proper auditing. (ii) repetition of international journals subscription and international books purchase from different universities and institutions should be avoided by following a policy of one country-one subscription \& one country-one library model by adopting $100 \%$ digitization of library materials.

(14) Attracting the top 100 foreign universities to India by offering free land in the outskirts of cities is an implementation strategy of the central government and will attract foreign investments and hence a good number of job opportunities and physical infrastructure development in the country. This also provides job opportunities to Indian teachers and researchers in the country decreasing the brain drain. Internationalization of higher education by providing open competition opportunities to them in India may decrease the student's travel to other countries for higher education thereby decreasing the money transfer i.e., foreign exchange to other countries.

(15) Creating Higher Educational Commission of India (HECI), a lobby free, corruption-free system and creating four verticals for regulation, accreditation, funding, and academics standard settings by excluding all office-bearers of existing accrediting agencies/councils need a black ocean strategy [11]. NEP-2020 will utterly fail if it gives old wine in a new bottle. The members of such policymaking and regulating committees should be role-models with proven records in the last five years.

(16) Central government should fix proper criteria for the appointment of qualified Vice-Chancellors to maintain high standards and to avoid lobbies. The appointment of obsolete Vice-chancellors as a role-models in the universities in terms of their recent research contributions and tech-savviness will depress the self-motivation of other faculty members along with their zeal for innovativeness.

\subsubsection{State Government Strategies :}

(1) Funding for State Universities based on their innovativeness and proven performance on graded autonomy through improved accreditation status.

(2) Raising Quality in State Universities by allocating enhanced annual budgets and monitoring the effective utilization of such funds for developmental activities.

(3) Infrastructural support for State public \& private universities by offering additional barren land which is not useful for cultivation purposes but can be utilized for expanding the campus for hostels, playgrounds, faculty housing facilities, etc.

(4) Schemes to attract foreign universities to increase competition by offering free land and low-cost financial facility or creating single window permissions for foreign direct investment. This strategy will increase the local employment and use of local resources for infrastructural development.

(5) Quality appointment strategy should be followed by the state government to all state universities and other public autonomous institutions by filling vacancies of faculty members at all levels in appropriate time to support them to achieve appropriate graded autonomy level to progress further. 
(6) Performance monitoring strategy - State government should appoint a clean but competent team to monitor the performance of universities and HEIs. The performance assessment format should be transparent and self-declared mode but should be verifiable by a third party.

(7) Supervising autonomy of state universities with light \& tight regulations - The graded autonomy provided to institutions and universities and its consequences on quality of service should be monitored every year through self-declared annual accreditation format. All self declaration formats should be prepared smartly by keeping the possibility of third party verification. The regulations should not give an opportunity to spoil the system by creating a door for corruption, lobby, and bribery.

(8) Strictly supervising Private Universities and Private autonomous colleges to maintain honesty and openness in accounting for their commitment to serving the society as not for profit organization. Any misappropriates in financial accounting should lead to the expulsion of responsible governing board members from the committee permanently.

(9) Appointment of Vice-Chancellors to State universities: Recent research contributions as role models and leadership qualities should be considered instead of reservation, community, political party affiliations, or bribery. State governments also fix proper criteria for the appointment of qualified ViceChancellors to maintain high standards and to avoid lobbies.

(10) Performance based increments, and promotions and accountability-based continuation strategy should be adopted for faculty members at all levels. Minimum academic and research performance targets should be fixed at all levels based on optimistic expectations. Annual increments and time bound promotions should be strictly based on the attainment of such minimum target level verified by a thirdparty source based on the transparent and open policy of the organization. For example, academic performance can be monitored by 360-degree feedback and research performance can be measured by the amount of IPR generated annually which can be verified by indexing sites like google scholar, SSRN, Research gate, Scopus, etc. Further performance verification is also possible by knowing the last five years h-index, and citations obtained through Google scholar/SSRN/Scopus with an authenticity check.

\subsection{Universities Strategies :}

Universities can contribute effectively to realize the objectives of National education policy 2020 by adopting sustainable (green ocean), competitive (red ocean), monopoly (blue ocean), and their mix called growth and prosper strategies. Universities should have a dynamic leader to implement educational innovations fearlessly to get first-movers-advantage in quality improvement. Some of the specific strategies under the above organizational strategies for higher education space are listed below:

\section{(1) Developing a progressive curriculum :}

Updating curriculum periodically as per current and future industry requirements by adding the latest changes and developments in the subject are essential to create interest among the students and to improve their innovativeness is essential. Developing new and effective pedagogy is also important to an effective and efficient teaching-learning process. The curriculum offered by universities and autonomous institutions should be competitive and monopoly to offer knowledge, new knowledge, skills, new skills, classroom experience and industry experience to uplift competency and teamwork of individuals.

\section{(2) Research focus :}

As per NEP-2020, research and publication is the focus of higher education. Research components in the curriculum in all levels of higher education stimulate independent and innovative thinking among students. Through developing researching mindset, students develop attitude for problem identification, identifying alternative solutions, analysing these solutions to find the optimum solution, and implementing such solution in real world problem. Following competitive and monopoly strategies, the universities can increase their contribution to scholarly publications and patents respectively. 
(3) Introduction of Multidisciplinary subjects :

Studying multidisciplinary subjects in higher education encourages students to think laterally and creatively while analyzing a problem or situation. Introducing STEAM based curriculum is found to be more effective than STEM based curriculum in the higher education system [22]. Universities should show their competitiveness and individuality in introducing effective multidisciplinary education model to higher education students through competitive and monopoly strategies, respectively.

(4) Choice of Teaching focus university or Research focus University or mixed university:

Depending on the goal set by the university based on the available resources, it can eventually end up into research focussed university or teaching focussed university. Teaching focussed universities have to compete with other universities while offering innovative undergraduate and postgraduate programmes. Hence, they have to follow competitive strategies suggested by Porter, M. E. [23]. The research focussed universities can prosper and become unique performers in selected super specialty areas and become centre of excellence in certain identified subjects which are futuristic by following the blue ocean strategy suggested by Kim, W. C. (2005) [13].

\section{(5) Competitive and unique infrastructure:}

It is known that generation $\mathrm{Z}$ and generation $\mathrm{A}$ are tech-savvy and health-savvy, and they are the customers of universities in future days [60]. In order to attract these new generations, universities have to focus on developing attractive physical and digital infrastructure including facilities for co-curricular and extra-curricular activities. It is expected that future generations can be attracted to the university education to increase GER by creating unique infrastructure in the campus both for academic teachinglearning and comfortable living facilities.

\section{(6) Monopoly research and contribution:}

Universities should develop specialized research centres in futuristic areas which are capable to contribute uniquely to solve basic needs for sustainability, advanced wants for comfortability, and dreamy desires for the fantasy of people in society by using monopoly strategy.

\section{(7) Low cost \& high quality for students:}

In order to attract students of all economic categories to higher education to enhance GER towards $100 \%$, universities should provide high quality education at a low cost. By using emerging technologies effectively and strategically, universities can increase their class size without compromising quality can become low cost players. Additionally, the administrators of the universities should be role-models to others by adopting simple lifestyles with honesty and openness.

\section{(8) Strategic collaboration with industries for internship \& job:}

Strategic collaboration is a part of the competitive strategy. By identifying and networking with related industries, the various departments of the universities can have a cordial relationship with national and international companies of selected industries to offer paid internship to the students and campus directed job opportunities to the graduates. This will in turn increases the popularity and brand value of the universities.

\section{(9) Collaborative strategy with other Universities and Institutions:}

In order to become low cost player and yet provide required infrastructural facilities to the students, the universities have to follow a collaborative strategy with other universities and super specialty educational institutions. This strategy will allow universities to share high-cost super specialty research and digital infrastructure facilities with each other allowing for optimal utilization of available infrastructure. This positive-sum game strategy makes every member institution in that collaboration as a gainer.

(10) Expansion strategy by absorbing weak colleges as constituent colleges:

One of the beauties of NEP-2020 is the well-defined life-cycle of HEIs. Accordingly, if an HEI is failed to expand and improve as an independent degree granting autonomous institution or university during 10 years timeline, eventually it will be absorbed by the affiliating university to become part of large 
supportive system. This is an opportunity for public funded colleges but a challenge and punishment for private institutions. Private institutions that come in this category will lose administrative control eventually and will become part of affiliating university. For private colleges, this is a do or die situation and unless they invest and expand themselves to get higher accreditation status by investing more in various infrastructures like physical, digital, innovative academic, intellectual property, emotional, and networking, they have to merge with their affiliating public university or eventually close down. Thus, all affiliated colleges should plan and implement proper expansion strategy to become an autonomous degree granting institution. Alternatively, public universities get an opportunity to absorb such weak colleges that fails to transform themselves into the next autonomous category. Based on such absorption of affiliated colleges as constituent colleges, universities should equip themselves to grow systematically in a big set-up of managing many constituent colleges by government support.

(11) University publication press and peer reviewed \& indexed journals:

The end of every research project is the publication of results in the form of copyrighted scholarly publication in journals or patented products or processes. In order to present developed new knowledge and new interpretations to the public society at comparatively high speed before they get obsolete, universities should plan to start or support their own publication unit for both books and indexed scholarly journals in different fields. This will help the faculty members and other student researchers to speed up their publications of inventions before they go out from the institution with their degree. This kind of horizontal expansion of university responsibilities adds value and speed-up the strategy of university growth.

\section{(12) Strategy for increment and promotions:}

Universities should adopt performance based annual increments and promotions by developing a progressive annual performance indicator format which should encourage the planned, committed, and dedicated contributing faculty members through hard work for prosper. The performance-based increment and promotion strategy will definitely speed-up the progress of universities.

\section{(13) Strategy of adopting Accountability [24-30]:}

Every university should develop a strong accountability policy for its employees from top to bottom. The leaders or heads of university and departments should be role-models and motivate others in their university and departments for exceptional performance to increase the research productivity of the university. Accountability should be strictly maintained and achievers should be promoted and nonperformers should be demoted or sacked out for the healthy development of the university. It should be noted that accountability of research contribution should be counted for teaching and administrative staff who have research backgrounds or are promoted from teaching and research departments.

\subsubsection{Other Higher Education Institutions Strategies :}

Other higher education institutions like standalone private colleges, multi-disciplinary private colleges, standalone government colleges, multi-disciplinary government colleges, private autonomous degree granting institutions, and government autonomous degree granting institutions have to follow a particular strategy like black ocean strategy for survival, green ocean for sustainability, red ocean for competition, blue ocean for monopoly, and white ocean mixed strategies for growth and prosper, to continue their existence and emerge as quality higher education institution to grow to next higher level of their proposed life-cycle as per NEP-2020. Some of the strategies to be adopted by such institutions are listed below:

(1) Decision on further investment-based growth for prosper or closure.

(2) Strategy for effective utilization of autonomy for growth and prosperity.

(3) Sustainable strategy for competing with public/private and foreign universities.

(4) Strategy for improving graded autonomy by continuous improvement in the quality of education and research.

(5) Strategy for good NIRF ranking by focusing on improvement of core criteria related parameters and scores.

(6) Strategy for improving NAC grading by continuous improvements in assessment criteria. 
(7) Strategy for attracting talented students by means of offering various facilities which may include, full fee waiver, scholarships, placement services, offering free hostel facilities, offering campus arranged education loan facility, offering computational devices, offering earn-while learn opportunities, etc.

(8) Strategy for institutional branding by creating emotional infrastructure among all stakeholders by providing quick requested services, by following open, humble, and honest outlook, appointing welltrained and humanistic employees, etc.

(9) Strategy for Industry tie-ups \& alumni network to enhance the credibility of the organization.

(10) Institutional Publication Press \& Journals to support staff \& students for timely publication of the papers and books.

\subsubsection{Strategies of Faculty Members of HIE :}

Highly motivated faculty members are the basic assets of any higher educational institution. Some of motivational strategies include:

(1) Learn more earn more : Faculty members who do not have research degree should register for parttime Ph.D. programme along with teaching in their colleges to fullfill the new regulation of minimum qualification to teach in colleges and universities.

(2) Faculty academic and research performance strategies: Faculty members should make a systematic annual plan to maximize the academic results of their teaching subjects, participate in faculty development programmes, and research and publications by individual contribution and by group contribution.

(3) Life long learning \& research strategies: To avoid obsolesce in the subject of specialization, faculty members of higher education institutions have to plan for continuous update of their knowledge by means of attending online and offline courses provided by various specialized agencies which offer MOOC including SWAYAM and get a certificate for the proof.

(4) Minimum two research papers publications as first author every year irrespective of their designation.

(5) Team and collaborative research to boost individual and organizational research performance.

(6) Competitive strategy to increase API scores to get annual increments and periodic promotions.

(7) Time management strategy and faculty performance as per the ABC model [31] faculty productivity.

(8) Conversion of taught subject notes into Book publication which is free from plagiarism.

(9) Involvement of student teams in research \& publication/patent by incorporating research components in UG and PG curriculum using institutional autonomy.

(10) Networking with Industries for collaborative projects/consultancy opportunities to further enhance API score-based performance.

(11) Publish, publish, more publish, or perish: This can be done by expanding the research team by adding UG students, PG students, Research students, faculties from other departments, colleges, institutions, universities, and of different countries as well as by different industries. Such a big collaborative team can publish high quality papers through collective efforts.

\subsubsection{Strategies of Students of HEIs :}

The students of higher education institutions should follow a strategy of maximizing the benefits and minimizing the expenditure (both money and time) by identifying and encashing opportunities during their under-graduation and post-graduation studies in interested/identified areas.

(1) Choice of futuristic subject areas based on interest \& comfort.

(2) Get free-ship \& Scholarships offered by various agencies

(3) Earn while learn to get responsibility, additional life-skills, and value of money.

(4) Planned committed hard work to increase their competitive edge.

(5) Being tech-savvy \& incorporate scientific thinking in all decisions.

(6) Learn more - earn more strategy to acquire higher education and life-long learning.

(7) Identify a role-model to follow and to get inspired.

(8) Avail education loan instead of depending on hard earned money from parents. In many cases, the interest of education loans received from the banks can be subtracted from the income tax to be paid by them so that effective interest for education loans will be negligible. 
(9) To have networks with many friends belonging to different regions, religions, backgrounds, ideas, and attitudes.

(10) Involve in research and innovations by identifying problems and involving in developing solutions.

(11) Acquire multi-tasking skills, multi-field expertise, dual degrees, and intellectual properties like copyrights and patents.

(12) To work with many team projects, individual projects, and internships.

(13) To showcase hidden talent by participating in many co-curricular, extra-curricular activities, competitions, sports, and games.

(14) Developing the model of ideal student characteristics and comparing themselves with such characteristics for maximizing the personal, institutional, and social benefits.

\subsubsection{Strategies of HIE Aspirants :}

Various strategies to be followed by aspiring students for admission in an autonomous college/university are :

(1) Hope and belief of prospering through the chosen programme.

(2) Have high expectations from HEI.

(3) Identify and encash opportunities on various facilities and programs on the campus.

(4) Futuristic courses that can shape their career.

(5) Choosing a career based on personal strengths, weaknesses, interests, and environmental support.

(6) Choosing institutes/universities which offer innovative, low cost, and high quality programmes.

(7) Choosing institutes/universities which provide communicative skills, experimental skills, \& research skills.

(8) Choosing institutes/universities which offers free-ships, scholarships, Hostel facility, or commuting facility from home, etc.

(9) Campus placement support for internship and job placement.

(10) Pre-admission intensive counselling from HEIs.

(11) Earn while learn opportunities within and outside the campus.

(12) Education loan arranged from University or Institution.

(13) Strong alumni network.

(14) Public perception of the university/institution.

\subsubsection{Strategies of Citizens of the Countries :}

(1) Searching for a good, innovative, futuristic, quality, and competent university for their wards admission.

(2) Openness in terms of promises and reality of achievements.

(3) Contribute to quality education through paying Income tax.

(4) Take part in the progress of the university as a parent or alumni.

(5) Believing the organization based on its quality commitment, social perspectives, and brand value.

\subsection{Other Strategies}

\subsubsection{Clean but Competent members in Regulatory bodies :-}

It is essential to decrease the number of regulatory bodies and appointing clean but competent members with a certain minimum contribution to teaching and research individually. For example, all members of regulatory bodies should have at least 20 years of teaching experience and must have 40 first author scholarly publications and 100 publications as one of the authors in their subject. Further, they should have (1) at least 10 scholarly publications or 5 edited books during the last 5 years, (2) H-index at least 15 during last 5 years, and (3) at least 1,000 citations during the last 5 years. This rule should be strictly implemented for the appointment of every regulatory body members and should be continued throughout their service in the regulatory body. Any reservation for gender, state wise region, religion, and caste can be maintained within the above minimum entry standards.

\subsubsection{Light but Tight regulations for HEIs :-}

(1) Regulations for developing minimum physical infrastructure based on the number of students and type of subjects offered in UG, PG, and research levels. 
(2) Regulations for minimum digital infrastructure and sharing them with other universities and autonomous colleges. Such interconnected and integrated digital resources of all the universities and other HEIs creates a super-library at the national level. This integrated super library leads the development of a One country-One library model. Such a national super library can be further integrated and networked with similar digital libraries of other countries leading to the development of a universal digital library concept.

(3) Regulations for minimum academic standards to maintain quality education. The evaluation system should be redesigned as a continuous evaluation for competency and innovativeness-based credit system.

(4) Regulations for minimum Intellectual Property infrastructure by standardizing the minimum annual publications for research scholars, assistant professors, associate professors, and professors both as the first author and as one among team authors. The fourth year students of professional courses along with the faculty guide are expected to file at least one patent per team project.

(5) Regulation for minimum facilities \& quality of service standard to be provided by the universities and other autonomous HEIs. Every university and autonomous degree granting colleges have to develop best practices in teaching-learning process and have to disclose their unique student development model.

(6) Regulations for a minimum number of industry networks for every university and autonomous degree granting colleges. This is essential for providing industry integrated curriculum, student internship, and guest lectures from industry experts.

(7) Regulations for minimum academic and research standards for Vice-Chancellors. For example, Vice-chancellors should have at least 100 research publications with (1) at least 10 scholarly publications or 5 edited books during the last 5 years, (2) $\mathrm{H}$-index at least 15 during the last 5 years, and (3) at least 1,000 citations during last 5 years. This rule should be strictly implemented during every Vice-chancellor appointment in public and private universities and for the continuation of the post every year.

\subsubsection{Openness from Top to Bottom :-}

(1) Every salaried employee should display his annual performance on the organizational website which should be cross verifiable from other public sources.

(2) Openness should start from the top and percolate to the bottom of HE system.

(3) Like politicians who have to disclose their financial \& property assets every year, academicians should disclose their qualifications including degree certificates, IPR (scholarly articles, edited book, book chapters/ conference published papers, patents, and other copyright materials in the institutional website every year and this should be verifiable from the third-party source.

(4) Accountability should start from Higher Education Commission of India (HECI) and percolate to down through all four verticals: (a) the National Higher Education Regulatory Council (NHERC), (b) National Accreditation Council (NAC), (c) Higher Education Grants Council (HEGC), and (d) General Education Council (GEC). The chairman and members of these committees abide to transparent public disclosure and use technology extensively to reduce the human interface to ensure efficiency and transparency in their work.

(5) Other committees under these four verticals should show responsibility and accountability while nominating/appointing members and must follow transparent annual disclosure of their academic, research, and administrative performance.

(6) The state level education boards should also give priority to openness and transparency while appointing the members for various committees compulsorily.

(7) The appointment of Vice-chancellors, directors, and any other administrative cadre based on academic performance should have minimum norms based on both academic and research performance which should be verifiable from third party source thoroughly irrespective of any kind of state government and central government reservations. The annual continuation as well as promotions to 
higher cadres, should also strictly based on transparent self-disclosed annual performance and contribution to academic, research, and administrative responsibilities.

(8) The appointment and continuation of professors/associate professors/assistant professors in all $\mathrm{HE}$ organizations should be merit (cum reservation) based on an achieved minimum standard of performance. Self-disclosure of annual performance and verification by peers through third party source varication should be criteria of openness.

\subsubsection{Publish or Perish :-}

The national education policy is research focussed and the end part of every academic research is the publication and industrial research is commercialization. The tangible metric for research is the publication and the quality of research is through citation [32-34]. The minimum annual academic and research performance (AARP) should be standardized at a comparatively high level to boost the standard of higher education in the country. For example, the annual research performance of a professor/associate professor/assistant professor in HEI can be standardized as per the ABC model of annual research productivity [29-31,35-38]. The gist of the ABC model of annual research productivity is depicted in Table 4.

Table 4: Summary of the ABC model of annual research productivity [31]

\begin{tabular}{|l|l|l|l|}
\hline $\begin{array}{l}\text { S. } \\
\text { No. }\end{array}$ & Scholarly Research Item & Score & Total Score \\
\hline 1 & $\begin{array}{l}\text { Number of Scholarly Journal Articles } \\
\text { (A) per year }\end{array}$ & 2 per Article & $\mathrm{A} \times 2=\mathrm{x}_{1}$ \\
\hline 2 & $\begin{array}{l}\text { Number of Edited Books (B) per year } \\
\text { minimum 5 chapters } \\
\text { matents (C) per year }\end{array}$ & $\mathrm{B} \times 5=\mathrm{x}_{2}$ \\
\hline 3 & $\begin{array}{l}\text { Number of Chapters/Cases studies/ } \\
\text { Pater paper/chapter/ } \\
\text { case study/patent }\end{array}$ & $\mathrm{C} \times 1=\mathrm{x}_{3}$ \\
\hline \multicolumn{2}{|l|}{ Total Annual Research Productivity Score $\left(\mathrm{x}_{1}+\mathrm{x}_{2}+\mathrm{x}_{3}\right)$} & $\mathrm{X}$ \\
\hline
\end{tabular}

Table 5 : Minimum total Scores required for different cadres*

\begin{tabular}{|c|c|c|c|c|c|}
\hline $\begin{array}{l}\text { S. } \\
\text { No. }\end{array}$ & Academic Cadre & $\begin{array}{l}\text { Number of } \\
\text { Scholarly } \\
\text { Journal Articles } \\
\text { (A) } \\
\text { [score per paper } \\
=2]\end{array}$ & $\begin{array}{l}\text { Number of } \\
\text { Edited Books } \\
\text { (B) } \\
\text { [score per book } \\
=5]\end{array}$ & $\begin{array}{l}\text { Number of } \\
\text { Chapters/Cases } \\
\text { studies/ Patents } \\
\text { (C) } \\
\text { [score per paper } \\
=1 \text { ] }\end{array}$ & $\begin{array}{l}\text { Minimum } \\
\text { Annual } \\
\text { Total } \\
\text { score } \\
\text { required }\end{array}$ \\
\hline 1 & Vice Chancellor & $\begin{array}{l}\mathrm{x}_{1} \\
\mathrm{Ex}:(10) \times 2=20\end{array}$ & $\begin{array}{l}\mathrm{x}_{2} \\
\mathrm{Ex}:(1) \times 5=5\end{array}$ & $\begin{array}{l}\mathrm{x}_{3} \\
\mathrm{Ex}:(0) \times 1=0\end{array}$ & 25 \\
\hline 2 & Professor & $\begin{array}{l}\mathrm{x}_{1} \\
\mathrm{Ex}:(10) \times 2=20\end{array}$ & $\begin{array}{l}\mathrm{x}_{2} \\
\mathrm{Ex}:(1) \times 5=5\end{array}$ & $\begin{array}{l}\mathrm{x} 3 \\
\mathrm{Ex}:(0) \times 1=0\end{array}$ & 25 \\
\hline 3 & Associate Professor & $\begin{array}{l}x_{1} \\
\operatorname{Ex}:(8) \times 2=16\end{array}$ & $\begin{array}{l}\mathrm{x}_{2} \\
\mathrm{Ex}:(1) \times 5=5\end{array}$ & $\begin{array}{l}\mathrm{x}_{3} \\
\mathrm{Ex}:(0) \times 1=0\end{array}$ & 21 \\
\hline
\end{tabular}




\begin{tabular}{|l|l|l|l|l|l|}
\hline 4 & Assistant Professor & $\mathrm{x}_{1}$ & $\mathrm{x}_{2}$ & $\mathrm{x}_{3}$ \\
$\mathrm{Ex}$ & & Ex: $(6) \times 2=12$ & Ex: $(0) \times 1=0$ & \\
\hline 5 & Lecturer & $\mathrm{x}_{1}$ & $\mathrm{x}_{2}$ & $\mathrm{x}_{3}$ & 4 \\
& & Ex: $(2) \times 2=4$ & Ex: $(0) \times 5=0$ & Ex: $(0) \times 1=0$ & \\
\hline
\end{tabular}

* The scores in table 5 are calculated by assuming that the Vice-chancellor or professor publishes two scholarly articles as first author, eight articles with eight research scholars (one each), and one edited book per year. An associated professor has to publish two scholarly articles as first author, six articles with six research scholars (one each) and one edited book per year. An assistant professor publishers two scholarly articles as first author, four articles with four research scholars (one each) per year. A lecturer publishers two scholarly articles as the first author per year.

Table 5 suggests minimum annual productivity of individuals at different cadres and depending on their subjects, ideas, capability of acquiring related resources in the form of projects, collaboration, and ability of leadership to get maximum performance through their research team can perform better.

7.3.5 Annual Performance based increments \& promotions to faculty members \& administrators :A good academic and research system in the higher education space can be created if and only if it is made productive by continuous contribution by every member of it. How to make a system more productive is a million dollars question. The answer is the theory of accountability (Theory A) [25, 39]. Based on the postulates of Theory A and postulates of the postulates of the ABC model of institutional performance measurement, one can develop a model of improving the higher educational institutional output. Professors are the most important ingredients of the entire higher education system. Apart from teaching, they have to be role-model of the higher education system to motivate entire teaching and research community. Unfortunately, currently, they are considered as the laziest and nonperforming assets of the system. This is due to the following reasons:

(1) There is no annual evaluation based on minimum performance requirements. The current system does not allow the demotion of professors to any lower level. For example, a professor is expected to publish minimum of two scholarly papers per year as first author, eight scholarly papers with eight $\mathrm{Ph} . \mathrm{D}$. students resulting in ten scholarly papers per year of high quality irrespective of his other administrative responsibilities.

(2) No further promotion opportunity depresses motivation due to saturation of ambitions $\&$ mindset.

(3) A substantially high salary and age-based health consciousness do not permit enough time for academic \& research activities.

(4) Additional administrative work as a reason for not performing academic \& research activities.

(5) There is no hard and fast rule that a professor should guide 6 to $8 \mathrm{Ph}$.D. students at every point of time during their tenure.

The regulations of National Education Policy 2020 should use a strategy to overcome faculty underperformance by setting minimum performance targets as suggested in table 5 . The annual increment should be given to only those faculty members who earn minimum scores as per table 5 . The promotions should be performance based and not time bound. Based on faculty self-declaration of research performance which should be verifiable from a third-party agency, increments and promotions should be offered. A set of minimum expected performance criteria should be worked out for different faculty and administration categories and publicized to create awareness of their annual targets in every university [40].

\subsubsection{Periodic auditing organizational performance \& IPR :-}

Periodic auditing of organizational performance especially on its contribution to IPR (both copyrights and patents) are essential. These IPR should get prominent scores in NAC accreditation and NIRF ranking evaluation. The universities should develop an internal annual appreciation system by means 
of offering awards/medals to those faculty members, research scholars, and students who contribute maximum to institutional IPR.

\subsubsection{Punishing for inappropriateness - by means of hectic penalty :-}

The institutions and faculty members indulge in misleading the information related to the implementation of regulations and qualification \& publication information, should be punished severely with heavy penalty and disciplinary actions respectively to maintain a high level of dignity in the higher education systems.

\subsubsection{Use of Retired professors as Research guides :-}

The country is not utilising the experience and guiding spirit of many retired professors with a Ph.D. for developing the research work force in the country. Universities and autonomous institutions are finding a scarcity for research guides to fulfil the demand of $\mathrm{Ph}$.D. degree programmes in many subjects. Based on the guidelines of NEP-2020, Ph.D. degree is mandatory for appointments of faculty members of both at the college level and university level. This will surge the demand for a Ph.D. degree programme. To cater such demand, the only solution is to increase the Ph.D. seats by means of three strategies: (i) Increasing the upper limit of Ph.D. scholars to be guided at a given point of time by assistant professors, associated professors, and professors to 6, 8, and 10 respectively, (ii) Based on strict regulation for filling all vacancies of $\mathrm{Ph}$.D. scholars positions under professors who are usually reluctant to take students for Ph.D. with a reason of early retirement, and (iii) Appointment of retired interested professors as Research professors by offering small monthly remuneration in addition to monthly pension and allowing them to guide 10 to 12 research scholars.

\subsubsection{Use of full time research scholars as teaching/laboratory assistants by offering teaching assistantships : -}

As per a suggestion of NEP-2020, Ph.D. scholars should be exposed to teaching-training, evaluation, and curriculum development process either in the coursework period or during other time of their mega research. It is appropriate to use them as teaching assistants at the undergraduate level or as laboratory assistants to teach laboratory courses at both undergraduates and postgraduate levels. This suggestion can be implemented by HEIs by offering teaching/training assistance-ship to full time researchers. Accordingly, a teaching assistant will teach about 8 hours per week by taking theory, or tutorial classes, or laboratory training and has to involve in curriculum development, implementation, and evaluation process along with his/her regular responsibility of research. This model is a positive-sum game where both research scholar and institution are gainers. Institutions while calculating the teaching load, two full time research scholars teaching assistant workload should be treated as equivalent to one full time faculty workload. The research scholars also get the benefit of earning for their living expenditure while researching otherwise they should depend on their old parents hard-earned money. This model of offering teaching assistance-ship to full time researchers attracts many talented youngsters to enroll for $\mathrm{Ph} . \mathrm{D}$. programme before joining for a job which in turn increases GER of research admissions in the country.

Based on the above discussion, table 6 is developed and is contains the summary of various strategies suggested to stakeholders for effective implementation of NEP-2020.

Table 6: Various strategies suggested to different stakeholders for implementation

\begin{tabular}{|l|l|l|l|}
\hline S. No. & $\begin{array}{l}\text { Stake-holders of NEP- } \\
\mathbf{2 0 2 0} \text { (India) }\end{array}$ & $\begin{array}{l}\text { Implementation } \\
\text { strategies suggested }\end{array}$ & Explanation \\
\hline 1 & Central government & $\begin{array}{l}\text { Blue ocean } \\
\text { (Monopoly) strategy }\end{array}$ & $\begin{array}{l}\text { Through an act central government } \\
\text { creates a light but tight regulations, } \\
\text { implement, monitor, and control it } \\
\text { with utmost care }\end{array}$ \\
\hline
\end{tabular}




\begin{tabular}{|c|c|c|c|}
\hline 2 & State governments & $\begin{array}{l}\text { Green ocean } \\
\text { (Sustainable) strategy }\end{array}$ & $\begin{array}{l}\text { Supporting \& guiding HEIs to } \\
\text { realize their objectives }\end{array}$ \\
\hline 3 & Universities & $\begin{array}{l}\text { (1) Red ocean } \\
\text { (competitive) strategy } \\
\text { (2) Blue ocean } \\
\text { (monopoly) strategy }\end{array}$ & $\begin{array}{l}\text { (1) Student service through } \\
\text { competitive strategy including low } \\
\text { cost, service differentiation, } \\
\text { academic facility innovation, } \\
\text { course and campus expansion, and } \\
\text { collaboration with industries. } \\
\text { (2) Faculty performance } \\
\text { monitoring through monopoly } \\
\text { strategy using the theory of } \\
\text { Accountability }\end{array}$ \\
\hline 4 & $\begin{array}{l}\text { Other higher education } \\
\text { institutions }\end{array}$ & $\begin{array}{l}\text { Red ocean } \\
\text { (competitive) strategy }\end{array}$ & $\begin{array}{l}\text { (1) Student service through } \\
\text { competitive strategy } \\
\text { (2) Faculty performance } \\
\text { monitoring through monopoly } \\
\text { strategy }\end{array}$ \\
\hline 5 & $\begin{array}{l}\text { Faculty members \& } \\
\text { Administrators }\end{array}$ & $\begin{array}{l}\text { (i) Green ocean } \\
\text { (sustainable) strategy } \\
\text { (ii) Leadership } \\
\text { strategy }\end{array}$ & $\begin{array}{l}\text { (1) Sustainable through committed } \\
\text { involvement. } \\
\text { (2) Role model to others through } \\
\text { extraordinary performance }\end{array}$ \\
\hline 6 & Students of HEIs & $\begin{array}{l}\text { (i) Blue ocean } \\
\text { (Monopoly) strategy } \\
\text { (ii) Red ocean } \\
\text { (competitive) strategy }\end{array}$ & $\begin{array}{l}\text { (1) Innovativeness \& Competency } \\
\text { (2) Competitiveness and all- } \\
\text { rounder }\end{array}$ \\
\hline 7 & Aspirants of HEIs & Alternative strategy & $\begin{array}{l}\text { Identifying and encashing } \\
\text { opportunities }\end{array}$ \\
\hline 8 & Citizens/Society & $\begin{array}{l}\text { White ocean mixed } \\
\text { strategy }\end{array}$ & $\begin{array}{l}\text { Expecting good service from HEIs } \\
\text { for the overall development of their } \\
\text { ward. }\end{array}$ \\
\hline
\end{tabular}

\section{STRATEGIES TO DEVELOP QUALITY IN UNIVERSITIES AND COLLEGES :}

The following strategies are useful while ensuring quality in higher education :

(1) Role-models as leaders can inspire all other stake-holders to perform better due to the fact that they prove the super-performance is possible. The top executives like Vice-chancellors, Directors, Principals, Deans, Head of the departments, and Professors should inspire and motivate others by their exceptional research contribution by themselves and through their research teams.

(2) Radical changes in the curriculum of the programmes every year based on changes in the relevant industry. 
(3) Focus on fast development on six essential infrastructures which include physical infrastructure, digital infrastructure, innovative academic infrastructure, Intelligent property infrastructure, emotional infrastructure, and networking infrastructure to become world-class university [9].

(4) University-industry integration for transfer of intellectual properties for industries for large scale production and supply to the society at comparatively low cost.

(5) Keeping politicians \& bureaucrats away from Universities \& Autonomous institutions academic affairs.

(6) Professors at all levels should involve in teaching \& research irrespective of any other administrative responsibilities.

(7) Audit \& accountability for academic \& research contributions every year until faculty retirement.

(8) Faculty enrichment \& removal of obsolescence by making compulsory two FDP certifications in the relevant and futuristic subjects every year failed to which no annual increment.

(9) University arranged student education loan with zero interest by stopping all fellowships \& scholarships based on gender, religion, and economic conditions.

(10) Focus on low-cost strategy with high quality through digitization of services, online video lectures, automation of examination \& evaluation to nullify corruption.

(11) Convert choice-based credit system into choice, innovativeness \& competency-based credit system.

\section{STRATEGIES FOR INSTITUTIONAL RESTRUCTURING \& CONSOLIDATION :}

The following strategies are useful for institutional restructuring and consolidation for growth and prosperity as per the life-cycle proposed by NEP-2020:

(1) Review of existing programmes offered by Colleges/departments and divisions of HEI. Based on globalization \& localization strategy of UG, PG, and research programmes in different subjects, start new programmes or close obsolete programmes.

(2) Start new colleges/departments in collaboration with global \& local industries. This helps to provide internship, to get industry experienced guest faculty, and placements to the graduating students.

(3) Evaluate and audit the existing programmes in terms of their admissions, graduate outcomes, placements, future demands, financial viability, and possible innovations.

(4) Evaluate the competency of faculty members teaching a particular course. Faculty members who show an attitude of continuous improvement and tech-savviness are only potential trainers to guide the students.

(5) Identify and evaluate new potential areas to start UG, PG, \& Research programmes and start at least two new colleges/departments or divisions every year as a part of continuous expansion.

(6) If the college is affiliated to a university, acquire the required infrastructures to grow as an autonomous degree granting college. For this, seek for long-term low-cost finance from banks or any other financial investment source. By using any kind of survival strategy, an affiliated college can convert itself as an autonomous college. Otherwise, it will lose its existence and will end up with either constituent college of the affiliating university or will eventually die-down.

(7) The private affiliated colleges which do not have sufficient physical infrastructure to elevate as multi-disciplinary autonomous degree granting colleges can implement a strategy to get autonomy by collaborating with similar colleges of a particular community and can emerge as a consolidated cluster of degree granting autonomous college or even a private university.

\section{STRATEGIES FOR MORE HOLISTIC \& MULTIDISCIPLINARY EDUCATION :}

The following strategies are helpful in converting existing colleges and universities into more and more holistic in-terms of value based and multidisciplinary education:

(1) Equal importance to multidisciplinary education and super-specialty education by developing and adopting STEAM model instead of STEM model of curriculum [22, 41-42].

(2) Adding experimental learning part and skill-oriented learning part in undergraduate curriculum as employability and entrepreneurship enhancement strategy.

(3) Adding two papers of 50 marks (unlike other papers of 100 marks) as ESEP (Employability Skill Enhancement Papers) compulsorily in every semester for internal evaluation based marks will definitely a differentiation strategy for HEIs. 
(4) Identifying institutional core values and making efforts to inculcate them in every stake-holder of the HEI is a unique differentiation strategy [43].

(5) Planning, implementing, and listing the innovations and best practices the organization is following and giving wide publicity for such innovations and best practices is a branding strategy [44].

\section{STRATEGIES FOR OPTIMAL LEARNING ENVIRONMENT \& STUDENT SUPPORT :}

The strategies suggested to create world-class universities [9] will help in planning an optimum learning environment and student support. This include:

(1) Create good, attractive, state-of-the-art physical infrastructure with facilities required for effective and experimental learning through well-equipped labs, library with adequate digital resources, sports \& games, nutritious food, clean drinking water, modern transportation facility, and neat \& clean hostels. Aesthetic building and green campus attract youths to higher education.

(2) Develop and procure state-of-the-art digital infrastructure for providing effective information at the right time.

(3) Institutional academic model called integrated student development model as innovative academic infrastructure has to be developed to show the uniqueness of the university/Institution in serving the students [45-46].

(4) Identifying, appointing, and nurturing research-oriented innovators, even at higher cost by offering additional incentives is beneficial to the institution to create intellectual property rights (IPR) infrastructure in form of copyrights and patents. Such IPR in the university or institutional name allows technology transfer to the industries.

(5) By means of creating a student friendly and faculty supportive environment in the university campus by identifying and solving their problems and providing comfortable facilities to them, the university can create belongingness of all stakeholders with the university. Such belongingness and secured environment in the campus creates emotional infrastructure for higher educational institution. By providing optimum learning environment and student support activities, universities can enhance emotional infrastructure asset from parents, alumni, industries, and public's perception.

(6) By having collaboration with many industries and creating the curriculum as per industry requirements, the university/institution provide an opportunity of paid internship to its students from relevant industries. Such industry-networked infrastructure creates complete learning model enhances the confidence among students and produces innovative graduates who are employable and entrepreneurable.

\section{STRATEGIES FOR TRANSFORMING THE REGULATORY SYSTEM OF HE :}

(1) Set up a completely new regulating committee as Higher Education Commission of India (HECI) with proven super-leaders derived from various backgrounds. A super-leader is a leader who is a rolemodel to others due to his hard-effort based exceptional contributions to society which is individual and team based [47-48]. The achievements and contribution will not be affected by internal and external variables like age, administrative responsibilities, family background, etc. For example, Dr. C. N. R. Rao, Dr. G. S. Agarwal, Dr. V. P. N. Nampoori, Dr. Bhushan Patwardhan, etc.

(2) Keep all non-performing members of current higher education set-up including UGC, AICTE, MCI, DCI, INC, PCI, ICAR, VCI, NCTE, CoA, NCVT, NAAC, etc, politicians, and bureaucrats out of the four vertical committees under Higher Education Commission of India (HECI), i.e., NHERC for regulation, NAC for accreditation, HEGC for funding, and GEC for academic standard setting.

(3) Develop light but tight regulation to convert universities and other HEIs relevant and contemporary for $21^{\text {st }}$ century education. Impose heavy penalty and accountability on administrators for dereliction of responsibilities, attempts on corruption, and favourism.

(4) Annual evaluation and accountability for top level academic and administrative leaders for their teaching, research, and administrative contributions to continue in their position as committee members of four verticals or vice-chancellors of universities or directors of Institutions. Based on publicly 
available data, it is argued that top committee members and vice-chancellors are usually become nonperformers due to their age and long duration (4 to 5 years) of the tenure period of their position.

(5) Open recruitment system: For top decision making positions belonging to four vertical committees recruitment of chairman and members should be carried out through advertisement in the higher education Commission of India (HECI) website and appointment should be from open pool applicants with minimum standardized contributions to academic and administrative responsibilities, and research based on publications during last 5 years. Thorough verification should be done by means of the thirdparty open access verification sources using smart and tech-savvy experts.

(6) Removal of obsolete people from Search/recruitment Committees: Through standardizing recruitment regulations, both central and state governments should avoid obsolete people who have not done significant contribution to the academics or research using their position during the last five years and are not tech-savvy to verify their performance through open access information resources. For example, studies show that $70 \%$ of vice-chancellors of Indian universities have not guiding for research scholars and not published at least two scholarly papers per year during their tenure. Appointing them further as search committee or recruitment committee members may not fulfil the objective of recruiting a competitive suitable person to the designated position.

\section{STRATEGIES FOR TECHNOLOGY USAGE AND INTEGRATION :}

Various strategies for technology usage and integration include:

(1) Development and use of indigenous technology platform for online teaching \& training with a slogan of One country-one online platform.

(2) Training the faculty members to use Artificial Intelligence \& robotics technology and Virtual reality \& Augmented reality technologies in teaching and training methods by preparing them using national training portals like SWAYAM.

(3) Focus in introducing emerging technologies of the $21^{\text {st }}$ century like ICCT underlying technologies and Nanotechnology in engineering, pharmaceutics, and health sciences professional education and research as they are disruptive technologies and have capabilities to solve basic problems on human needs, advanced problems related to comfortability, and dreamy desire problems related to the fantasy of human beings in society [49-58].

(4) The central government should open general research facilities in important technology areas like agri-technologies, water-technologies, energy-technologies, space-technologies, biotechnology, genetic-technologies, ICCT underlying technologies, nanotechnology, and in basic sciences for researchers of universities and autonomous institutions. Optimum utilization of these common facilities should be ensured. This will also eliminate duplication of research facilities in many laboratories of universities which are underutilized due to maintenance problem.

(5) Free internet for every citizen: Central government should develop technology infrastructure to provide free and high-speed internet facility both the urban and rural population. This will support the realization of the digital India dream by creating a platform to realize digital education, digital economy, digital governance, digital services in primary, secondary, tertiary, and quaternary industries.

\section{STRATEGIES FOR ONLINE \& DIGITAL EDUCATION :}

Digitization strategy allows development and sharing information resources effectively in the following ways:

(1) Developing institutional online teaching platform and teaching-learning models.

(2) Training faculty members and students for effective use of the online digital platforms.

(3) Developing digital content for curriculum using various multimedia simulation effects.

(4) Strategies to use Artificial intelligence and virtual reality in effective online teaching for both theoretical and practical subjects. Artificial intelligence, virtual \& augmented reality, and simulation techniques can be effectively used in quality teaching and training for generation $\mathrm{Z}$ and generation $\mathrm{A}$ students [59-60] in both online and classroom-based education.

(5) Developing institutional digital library with global networking to access any information ubiquitously by all stakeholders.

15. STRATEGIES NEEDED TO PROMOTE RESEARCH \& INNOVATION : 
The main objective of NEP-2020 is to accelerate the research contributions of the citizens by improving and stimulating their innovativeness and competitiveness [61]. The research culture of the students at the higher education level can be enhanced in the following ways:

(1) Adding research components in UG \& PG programmes.

(2) Insisting compulsory publications/patents in the last year of UG \& PG levels.

(3) Annual Research Indicators based on ABC productivity model to increase faculty teamwork and connecting it with annual increments and promotions.

(4) Organizing conferences \& seminars for creating an effective research network.

(5) Starting institutional publications to speed-up research communications and scholarly publications.

(6) Making copyright or patent compulsory for scholarly research in researcher and institution/university name from Copyright office, Government of India and Indian Patent office, Government of India respectively.

\section{RECOMMENDATIONS :}

The following recommendations are proposed based on the analysis of NEP-2020 using Focus-group method for effective implementation to fulfil its objectives :

(1) Focusing on the Top-Down approach of implementation will give a better result.

(2) Identifying Role-models who have clean and proven track records in academics, research, and administrations with responsibility and accountability while appointing to the officials of top policy making authority - Higher Education Commission of India (HECI) and its four verticals.

(3) Responsibilities of implementation should be given to a team of people who have a proven record of hard work in the field instead of lobbies, influence, favourism based on gender, geographical region, religion, community, other country experience, and political ideology.

(4) Regulatory bodies should allow higher education institutions to perform better by providing functional autonomy to improve the quality of service [62-63].

(5) Regulations for HEIs should be light but tight as mentioned in NEP-2020. These regulations should impose many targets for HEIs to fulfill the objectives of NEP-2020 and strict monitoring of these targets by a self-declaration system is essential. Such self-declarations should be verified by National Accreditation Council during accreditation inspection for graded accreditation.

(6) Public and private organizations and their faculty members should be treated equally for research funding purposes.

(7) Central government should offer free land to all Universities (Public, Private, and Foreign) in equal amounts in the outskirt of cities for their expansion.

(8) Central government should provide interest free infrastructure development long term loan for all private and foreign universities in the country.

(9) Autonomy to avoid One Country-One Curriculum: Universities and Institutions should get autonomy to decide their curriculum for different courses in order to differentiate them in the higher education space. Any move from any agencies on one state - one curriculum for all universities questions the requirement of many universities. One country-one curriculum will not promote diversity in teaching and learning based knowledge and leads to the concept of one country-one university.

(10) Free internet for everyone: Free internet facility to be offered by central government/state government enhances higher education coverage to economically low-level people and in turn, increases GER of higher education and digitization of the economy of the country. 
(11) One country-one library: Through the digitization of books, journals, and other information resources [64], the country should adopt one country -one library policy. This will cut down the huge cost of creating physical libraries in the country, decreases a substantial amount of foreign exchange spending, and closes the opportunity for many corrupt dealings.

(12) Central research facilities: Open-up the central research facilities in each state for optimum utilization of costly \& imported research instruments by many researchers rather than completely controlled and used by a single group.

(13) Publish \& retain copyright: Universities should start their own publication units for books \& peer reviewed journals to avoid publications in predatory journals and to retain copyright with authors. This will also contribute to decreasing the country's foreign exchange.

(14) Appointment of vice-chancellor and other statuary officers should be strictly monitored by the Higher Education Commission of India (HECI) in central, state, private, and foreign universities in the country to maintain academic values, authenticity, holistic education to pursuit of knowledge (Jnan), wisdom (Pragyaa), and truth (Satya), and to curb the commercialization of education. Further, the leadership positions and heads of institutions should possess high academic qualifications and demonstrated administrative and leadership capabilities along with abilities to manage complex situations as mentioned in the policy. Table 7 suggests ten criteria model of checking eligibility for the appointment of the vice-chancellor and members of four verticals of HECI. A vice-chancellor or member for HECI candidate should qualify the minimum required scores in at least 7 criteria out of 10 mentioned as $7 / 10$ criteria of VC eligibility.

Table 7: 7/10 Criteria suggestion for minimum eligibility for the appointment of vice-chancellor of any university in India member for four verticals of HECI irrespective of statutory reservations

\begin{tabular}{|l|l|l|}
\hline S. No. & Criteria & Minimum requirement \\
\hline 1 & $\begin{array}{l}\text { Academic Result during last 5 years in } \\
\text { UG/PG teaching* }\end{array}$ & $80 \%$ average \\
\hline 2 & Student Feedback during last 5 years * & $60 \%$ \\
\hline 3 & Number of Books written with ISBN** & 04 \\
\hline 4 & $\begin{array}{l}\text { Number of Scholarly Research Papers } \\
\text { published during last 5 years ** }\end{array}$ & 50 \\
\hline 5 & $\begin{array}{l}\text { Total number of Scholarly Research } \\
\text { Papers published ** }\end{array}$ & 100 \\
\hline 6 & $\begin{array}{l}\text { Number of Citations during last 5 years ** } \\
\text { Total number of Citations in their name ** }\end{array}$ & 1,000 \\
\hline 7 & H-Index during last 5 years ** & 15 \\
\hline 8 & $\begin{array}{l}\text { Total H-index ** } \\
\text { currently guiding) } * * *\end{array}$ & 30 \\
\hline 9 & & 10 \\
\hline 10 & & \\
\hline
\end{tabular}

(* To be verified by institutional website) 
(**To be verified from third party sources like Scopus/Web of science/Google scholar/Research gate/SSRN/others)

(*** To be verified from inflibnet-Shodhganga and institutional websites.)

(15) Private, and Foreign universities in the country should show their social obligation by offering a considerable amount of fee waiver (free-ship) and scholarships (with $50 \%$ of course fees) for meritorious students. As per the policy, $20 \%$ of free seats without charging course fee and $30 \%$ of seats with $50 \%$ course fee should be made compulsory for all years and for all courses of all private and foreign universities for their Indian operations.

(16) Most respectable and responsible stakeholders of higher education systems are professors and they should be held responsible for annual performance and accountability. Every professor should guide 610 research scholars and teach at least four classes per week for UG or PG students irrespective of their administrative responsibilities with the sole intention of transforming higher education by improving the quality as expected in NEP-2020.

(17) Utilization of retired professors as research guides by giving honorary monthly salary until they maintain good health to do so irrespective of their age. This is in addition to monthly pension the government is offering to them. This strategy solves the scarcity of research guides for Ph.D. programmes and helps to fulfil the demand for Ph.D. seats in the country.

(18) Dual degree programmes should be encouraged to acquire multiple skills may be one in a professional area and another in arts or language using online mode of education as ideal education model [65-67].

(19) National Educational Technology Forum (NETF) should take responsibility to develop \& provide an indigenous online teaching-learning platform like Zoom/Google meet to all educational institutions at low annual subscription charges.

(20) National Educational Technology Forum (NETF) also should improve and expand the reachability of technology-based education platforms like DIKSHA/SWAYAM, and should offer through universities as a part of compulsory modules in every semester. The course contents of these online programmes should be upgraded by using artificial intelligence, simulation, and virtual reality technologies.

(21) Research funding in universal technologies like twelve ICCT underlying technologies [49-53] and nanotechnology [68-76] should be prioritized due to the reason that they are capable to solve basic problems, advanced comfortable problems, and dreamy desire problems of society [77].

(22) As mentioned in the policy and its interpretation [65-67], higher education should have three blended components as classroom-based teaching-learning part, SWAYAM based online subjects' part, and other subjects from any online-distance education institutions or universities. The evaluation system of the university should also focus on acquiring competency in these subjects of three modes along with choice-based credit system.

(23) Since professors should be role-models in HES, the appointment of professors should be based on an annual review. Annual increment or demotion to the lower category should be possible for nonperformers based on accountability principles.

(24) Appointment of Vice-Chancellors/Directors of universities and Colleges should be transparent and their research contribution and $\mathrm{H}$-index of quality research should be verifiable from third party sources like google scholar, Scopus, or SSRN. Further annual continuation should be based on review of their annual performance for academics, research, and administration contribution. 
(25) Systematic implementation plan in phased manner and communicating it from top to bottom in the downward ladder of higher education institutions through faculty members is crucial. The implementation of NEP 2020 can be completed if and only if it is made "faculty focussed" by involving them in the quality improvement process. Faculty member's involvement, commitment, and dedication in implementation only can make the objectives of Indian National Education Policy 2020 as a real and successful.

(26) The higher education model should be knowledge oriented for research, skill oriented for innovations, and experimental oriented for learning so that the HE service can be "student-centred" [7879].

(27) In order to encourage life-long learning \& research, the higher education council should promote post-doctoral certificate programmes and post-doctoral degree programmes leading to D.Sc., D.Litt., etc. in all research focussed universities. This will redefine the research targets of Ph.D. graduates and accelerate their research contribution to next higher level through collaborative research and eliminates saturation in research publications.

\section{CONCLUSION :}

India is geared up to implement the guidelines of National Education Policy 2020 throughout the country to reform and make radical changes in school education and higher education with an objective of creating a new education system which should empower the youngsters and boost their confidence to create new knowledge, new skills, along with human values to solve current and future problems and challenges of the civilized society by means of their enhanced innovative ability and tech-savviness. It is known that technology which is an application of scientific thinking has the capabilities to improve the quality of life of everyone in this universe and quality education is the foundation for it. With the objective of providing value based, knowledge based, and skill based higher education for everyone in the country, the new education policy has many intrinsic propositions to improve the quality of school and higher education to creating interest in their chosen area to find challenges and converting them into opportunities by discovering innovative solutions to make life comfortable and successful with expected happiness. The quality higher education has the objective of developing human beings who are responsible for creating better society by means of improved human value-based discipline, and respecting each other for growth and prosperity. Quality higher education also makes everyone to contribute to discovering new technology, adopting new technology, or promoting new technology which can contribute to the progress of society. It is expected that the new education policy which is research focussed, will accelerate the attainment of the above objectives and makes every stakeholder as innovator.

The systematic implementation of the proposed policies by creating multi-disciplinary, degree offering, autonomous higher education institutions with students belonging to different disciplines at UG, PG, and research levels guided by highly focussed and committed teachers as the intellectual property will create an atmosphere of innovative and lateral thinking. To make the implementation is effective, a topdown approach among the stakeholders is suggested. By means of power mantras like clean but competent members of implementation committees, light but tight regulations, openness from top to bottom, publish or perish, annual performance based increments \& promotions, periodic auditing of organizational performance through NAC, punishing for inappropriateness by means of hectic penalty, faculty focused and student centred national education policy 2020 can be implemented successfully with its stated timeframe of $10-15$ years.

REFERENCES :

[1] National Education Policy 2020, Ministry of Human Resource Development, Govt. of India. https://www.education.gov.in/sites/upload_files/mhrd/files/NEP_Final_English_0.pdf

[2] Aithal, P. S., \& Aithal, S. (2019). Analysis of Higher Education in Indian National Education Policy Proposal 2019 and Its Implementation Challenges. International Journal of Applied Engineering and Management Letters (IJAEML), 3(2), 1-35. 
[3] Sunil Kumar Saroha, \& Uttam Anand (2020). New instruction procedure 2020 Highlights: To see huge movements in schools and advanced edification. IOSR Journal of Humanities and Social Science (IOSR-JHSS), 25(8), 59-62.

[4] Aithal, P. S., \& Aithal, S. (2020). Analysis of the Indian National Education Policy 2020 towards Achieving its Objectives. International Journal of Management, Technology, and Social Sciences (IJMTS), 5(2), 19-41.

[5] Jha, P., \& Parvati, P. (2020). National Education Policy, 2020. (2020). Governance at Banks, Economic \& Political Weekly, 55(34), 14-17.

[6] Suryavanshi, S. (2020). Reflections from a Comparative Study for Reimagining Indian Universities. UNIVERSITY NEWS, 58(33), 96-102.

[7] Kumar, K., Prakash, A., \& Singh, K. (2020). How National Education Policy 2020 can be a lodestar to transform future generation in India. Journal of Public Affairs, 20(4), e2500. https://doi.org/10.1002/pa.2500

[8] Deb, P. (2020). Vision for Foreign Universities in the National Education Policy 2020: A Critique. Rajiv Gandhi Institute for Contemporary Studies, 1-29. https://www.rgics.org/wpcontent/uploads/Foreign-Universities-in-India-Palash-Deb.pdf

[9] Aithal, P. S., \& Aithal, S. (2019). Building World-Class Universities: Some Insights \& Predictions. Building World-Class Universities: Some Insights \& Predictions. International Journal of Management, Technology, and Social Sciences (IJMTS), 4(2), 13-35.

[10] Aithal, P. S., and P. M. Suresh Kumar (2015). Applying SWOC Analysis to an Institution of Higher Education. International Journal of Management, IT and Engineering (IJMIE), 5(7), 231247.

[11] Aithal, P. S., \& Kumar, P. M. (2015). Black Ocean Strategy-A Probe into a new type of Strategy used for Organizational Success. GE-International Journal of Management Research (GEIJMR), 3(8), 45-65.

[12] Markopoulos, E., Kirane, I. S., Piper, C., \& Vanharanta, H. (2019, September). Green ocean strategy: democratizing business knowledge for sustainable growth. In International Conference on Human Systems Engineering and Design: Future Trends and Applications (pp. 115-125). Springer, Cham.

[13] Kim, W. C. (2005). Blue ocean strategy: from theory to practice. California management review, 47(3), 105-121.

[14] Muhammad, S., Rosmaini, T., \& Mehwish, R. (2017). Mediating Role of Innovation Strategy Between Porter's Red Ocean Strategy and Innovative Performance. Advanced Science Letters, 23(9), 9239-9242.

[15] Aithal, P. S. (2016). The concept of ideal strategy and its realization using white ocean mixed strategy. International Journal of Management Sciences and Business Research, 5(4), 171-179.

[16] Daugherty, P. J., \& Pittman, P. H. (1995). Utilization of time-based strategies. International Journal of Operations \& Production Management. 15(2), 54-60.

[17] Aithal, P. S., \& Aithal, A. (2018). The Concept and Importance of Alternative Strategy as Parallel Strategy to be followed in Organizational Decisions to Ensure Success. International Journal of Management, Technology, and Social Sciences (IJMTS), 3(2), 1-15.

[18] Papke-Shields, K. E., \& Boyer-Wright, K. M. (2017). Strategic planning characteristics applied to project management. International Journal of Project Management, 35(2), 169-179.

[19] Aithal, P. S., \& Kumar, P. M. (2016). Organizational behaviour in 21st century-'Theory A' for managing people for performance. IOSR Journal of Business and Management (IOSR$J B M), 18(7), 126-134$. 
[20] Dodgson, M. (1991). Technology learning, technology strategy and competitive pressures. British Journal of Management, 2(3), 133-149.

[21] Kumar, M. J. (2020). National Education Policy: How does it Affect Higher Education in India?. IETE Technical Review, 37(4), 327-328.

[22] Aithal, P. S., \& Aithal, Shubhrajyotsna. (June 2019). Innovation in B.Tech. Curriculum as B.Tech. (Hons) by integrating STEAM, ESEP \& IPR features. International Journal of Case Studies in Business, IT, and Education (IJCSBE), 3(1), 56-71.

[23] Porter, M. E. (1982). Competitive strategy. RAE-Revista de Administração de Empresas, 22(2), 44-46.

[24] Aithal, P. S., \& Kumar, P. M. (2016). Organizational behaviour in 21st century-'Theory A' for managing people for performance. IOSR Journal of Business and Management (IOSR$J B M), 18(7), 126-134$.

[25] Aithal, P. S., \& Kumar, P. M. (2016). Theory A for Optimizing Human Productivity. IRAInternational Journal of Management \& Social Sciences (ISSN 2455-2267), 4(3), 526-535.

[26] Aithal, P. S. (2018). How to Boost Faculty Research Performance in HEI's to Improve Intellectual Property by Integrating It with Faculty Compensation-A 'Theory of Accountability' Based Framework. International Journal of Management, Technology, and Social Sciences (IJMTS), (2018), 3(2), 130-151.

[27] Aithal, P. S., \& Kumar, P. M. (2019). Autonomy in Higher Education-Towards an Accountability Management Model. International Journal of Management \& Development, 6(10), 166-175.

[28] Aithal, P. S., \& Kumar, P. M. (2016). Comparative analysis of theory X, theory Y, theory Z, and Theory A for managing people and performance. International Journal of Scientific Research and Modern Education (IJSRME), 1(1), 803-812.

[29] Aithal, P. S., \& Kumar, P. M. (2017). Interconnecting Theory A and ABC Model of Organizational Performance. International Journal of Management, Technology and Social Sciences (IJMTS), Srinivas Publishers, 1(1), 1-13.

[30] Aithal, P. S., \& Kumar, P. M. (2016). Application of Theory A on ABC Model to enhance Organizational Research Productivity in Higher Education. International Journal of Advanced Trends in Engineering and Technology (IJATET), 1(1), 142-150.

[31] Aithal, P. S., Suresh Kumar, P. M. (2016). ABC Model of Research Productivity and Higher Educational Institutional Ranking. International Journal of Education and Management Engineering (IJEME), 6(6), 74-84.

[32] Aithal, P. S. (2017). Comparative study of various research indices used to measure quality of research publications. International Journal of Applied and Advanced Scientific Research (IJAASR), 2(1), 81-89.

[33] Aithal, P. S. (2017). ABCD Analysis of Recently Announced New Research Indices. International Journal of Management, Technology, and Social Sciences (IJMTS), 1(1), 65-76.

[34] Aithal, P. S. \& Shubhrajyotsna Aithal (2019). Researcher Centric Scholarly Publication and Research Journals Classification - New Insight based Model. International Journal of Case Studies in Business, IT, and Education (IJCSBE), 3(2), 91-104.

[35] Aithal, P. S., Shailashri, V. T, Suresh Kumar, P. M. (2016). Analysis of ABC Model of Annual Research Productivity Using ABCD Framework. International Journal of Current Research and Modern Education (IJCRME), 1(1), 846-858.

[36] Aithal, P. S., \& Kumar, P. M. (2016). Application of Theory A on ABC Model to enhance Organizational Research Productivity in Higher Education. International Journal of Advanced Trends in Engineering and Technology (IJATET), 1(1), 142-150. 
[37] Aithal, P. S., \& Kumar, P. M. (2017). Interconnecting Theory A and ABC Model of Organizational Performance. International Journal of Management, Technology and Social Sciences (IJMTS), 1(1), 1-13.

[38] Aithal, P. S. (2016). Research Performance Analysis of Some Indian Top Business Schools Using ABC Model. International Journal of Computational Research and Development, 1(1), 70-83.

[39] Aithal, P. S. (2016). How to Increase Research Productivity in Higher Educational InstitutionsSIMS Model. International Journal of Scientific Research and Modern Education (IJSRME), 1(1), 447-458.

[40] Dundar, H., \& Lewis, D. R. (1998). Determinants of research productivity in higher education. Research in higher education, 39(6), 607-631.

[41] Aithal, P. S., \& Aithal, S. (2019, October). Essential infrastructures for world-class universities. In Proceedings of National Conference on Research in Higher Education, Learning and Administration (Vol. 1, No. 1, pp. 01-23).

[42] Aithal P. S. \& Shubhrajyotsna Aithal (July 2020). Importance of Arts \& Design in Liberal education STEAM model of Higher Education. Chapter I, pp. 1-24. Applied Arts Science in IT Age, Edited by Dr. P. K. Paul, New Delhi Publishers, New Delhi, India. ISBN: 978-93-88879-903.

[43] Aithal, P. S. (2016). Creating innovators through setting up the organizational vision, mission, and core values: a strategic model in higher education. International Journal of Management, IT and Engineering, 6(1), 310-324.

[44] Aithal, P. S., \& Kumar, P. M. (2015). How Innovations and Best Practices can Transform Higher Education Institutions: A case study of SIMS. International Journal of Management (IJM), 6(2), 83-98.

[45] Aithal, P. S., \& Kumar, P. M. (2015). Societal Expectation and Institutional Accountability in Higher Education. International Journal of Management, IT and Engineering, 5(7), 361-373.

[46] Aithal, P. S., \& Kumar, P. M. (2016). Student performance and Learning Outcomes in Higher Education Institutions. International Journal of Scientific Research and Modern Education (IJSRME), 1(1), 674-684.

[47] Aithal, P. S. (2016). Excellence in Individual Research \& Publications: Examining the Active Role of Role-models (Deans) of World Top Business Schools. International Journal of Engineering Research and Modern Education (IJERME), 1(2), 179-199.

[48] Aithal, P. S. (2018). Effect of Role Models-A Critical Study on the Recent Research Contribution of Vice-Chancellors of Selected Private Universities in India. International Journal of Management, Technology, and Social Sciences (IJMTS), 3(1), 118-139.

[49] Aithal, P. S., \& Madhushree, L. M. (2019). Information Communication \& Computation Technology (ICCT) as a Strategic Tool for Industry Sectors. International Journal of Applied Engineering and Management Letters (IJAEML), 3(2), 65-80.

[50] Madhushree L. M, Revathi Radhakrishnan, \& P. S. Aithal (Jan 2019). A Review on Impact of Information Communication \& Computation Technology (ICCT) on Selected Primary, Secondary, and Tertiary Industrial Sectors. Saudi Journal of Business and Management Studies, 4(1), 106127.

[51] Aithal, P. S. \& Madhushree L. M. (May 2019). Emerging Trends in ICCT as Universal Technology for Strategic Development of Industry Sectors. Chapter in a Book - IT and Computing for all the Domains and Professionals: The Emergence of Computer and Information Sciences, Edited by P.K. Paul, A. Bhuimali, K.S. Tiwary, and P. S. Aithal published by New Delhi Publishers, New Delhi. pp 1-26, ISBN: 978-93-88879-66-8. 
[52] Aithal, P. S., \& Shubhrajyotsna Aithal. (2019). Management of ICCT underlying Technologies used for Digital Service Innovation. International Journal of Management, Technology, and Social Sciences (IJMTS), 4(2), 110-136.

[53] Aithal, P. S. \& Shubhrajyotsna Aithal (July 2020). Information Communication and Computation Technology (ICCT) and its Contribution to Universal Technology for Societal Transformation. In "Information, Communications and Computation Technology (ICCT) The Pillar for Transformation" edited by P.K. Paul et al. published by New Delhi Publishers, New Delhi, India, pp. 1-28. ISBN: 978-93-88879-95-8.

[54] Aithal, P. S. (January 2016). Nanotechnology Innovations \& Business Opportunities : A Review. International Journal of Management, IT and Engineering (IJMIE), 6(1), 182-204.

[55] Aithal, P. S. and Shubhrajyotsna Aithal, (2016). Opportunities \& Challenges for Green Technology in $21^{\text {st }}$ Century. International Journal of Current Research and Modern Education (IJCRME), 1(1), 818-828.

[56] Shubrajyotsna Aithal \& Aithal, P. S. (2018). Concept of Ideal Water Purifier System to Produce Potable Water and its Realization Opportunities using Nanotechnology. International Journal of Applied Engineering and Management Letters (IJAEML), 2(2), 8-26.

[57] Aithal, P. S. \& Shubrajyotsna Aithal, (2016). Nanotechnological Innovations \& Business Environment for Indian Automobile Sector : A Futuristic Approach. International Journal of Scientific Research and Modern Education (IJSRME), 1(1), 296-307.

[58] Aithal, P. S. \& Shubhrajyotsna Aithal, (2016). Nanotechnology Innovations \& Business Opportunities in Renewable Energy Sector. International Journal of Engineering Research and Modern Education (IJERME), 1(1), 674- 692.

[59] Madhushree L. M, Bhuvana R, and Aithal P. S. (October 2020). Impact of COVID-19 on Redefining the Services of Educational Institutions using Ubiquitous Technology. International Journal of Management, Technology, and Social Sciences (IJMTS), 5(2), 266-282.

[60] Aithal, P. S. \& Shubhrajyotsna Aithal, (June 2020). Conceptual Analysis on Higher Education Strategies for various Tech-Generations. International Journal of Management, Technology, and Social Sciences (IJMTS), 5(1), 335-351.

[61] Srinivasa Rao, A. B., Kumar, P. M., \& Aithal, P. S. (2015). Strategic Planning in Higher Education Institutions: A Case Study of SIMS-VISION 2025. International Journal of Educational Science and Research (IJESR), 5(2), 29-42.

[62] Aithal, P. S., \& Aithal, S. (2019). Autonomy for Universities Excellence-Challenges and Opportunities. International Journal of Applied Engineering and Management Letters (IJAEML), 3(2), 36-50.

[63] Aithal P. S. \& Suresh Kumar P. M. (November 2019). Autonomy in Higher Education - Towards an Accountability Management Model. International Journal of Management \& Development, 6(10), 166-175.

[64] Aithal, P. S. (2016). Smart Library Model for Future Generations. International Journal of Engineering Research and Modern Education (IJERME), 1(1), 693-703.

[65] Aithal P. S. and Shubhrajyotsna Aithal (2014). Ideal education system and its realization through online education model using mobile devices, Proceedings of IISRO Multi Conference 2014, Bangkok, $140-146$.

[66] Aithal P. S. and Shubhrajyotsna Aithal (2015). An Innovative Education Model to realize Ideal Education System. International Journal of Scientific Research and Management (IJSRM), 3(3), $2464-2469$.

[67] Aithal, P. S. \& Shubhrajyotsna Aithal, (2016). Impact of On-line Education on Higher Education System. International Journal of Engineering Research and Modern Education (IJERME), 1(1), 225-235. 
[68] Aithal, P. S., \& Shubhrajyotsna Aithal, (2015). Ideal Technology Concept \& its Realization Opportunity using Nanotechnology, International Journal of Application or Innovation in Engineering \& Management (IJAIEM), 4(2), 153 - 164.

[69] Aithal, P. S., Shubhrajyotsna Aithal, (2015). A review on Anticipated Breakthrough Technologies of 21st Century. International Journal of Research \& Development in Technology and Management Sciences, 21(6), 112 - 133.

[70] Aithal, P. S. \& Shubhrajyotsna Aithal (2018). The Concept \& Characteristics of Ideal Energy System and its Realization Constraints. International Journal of Applied Engineering and Management Letters (IJAEML), 2(2), 127-137.

[71] Shubhrajyotsna Aithal \& Aithal, P. S. (2018). The Realization Opportunity of Ideal Energy System using Nanotechnology Based Research and Innovations. International Journal of Advanced Trends in Engineering and Technology, 3(2), 1-15.

[72] Architha Aithal \& Aithal, P.S. (2018). The concept of Ideal Drug \& Its Realization Opportunity using present Pharmaceutical Sciences Scenario. International Journal of Health Sciences and Pharmacy (IJHSP), 2(2), 11-26.

[73] Aithal P. S. \& Shubhrajyotsna Aithal (2016). Business Strategy for Nanotechnology based Products \& Services. International Journal of Management Sciences and Business Research (IJMSBR), 5(4), 139-149.

[74] Aithal, P. S. and Shubrajyotsna Aithal (2016). Nanotechnology Innovations and Commercialization - Opportunities, Challenges \& Reasons for Delay. International Journal of Engineering and Manufacturing (IJEM), 6(6), 15-25.

[75] Aithal, P. S. \& Shubhrajyotsna Aithal (2016). A New Model for Commercialization of Nanotechnology Products and Services. International Journal of Computational Research and Development, 1(1), 84-93.

[76] Aithal P. S. \& Shubhrajyotsna Aithal (2018). Nanotechnology based Innovations and Human Life Comfortability -Are we Marching towards Immortality ? International Journal of Applied Engineering and Management Letters (IJAEML), 2(2), 71-86.

[77] Aithal, P. S. \& Aithal, Shubhrajyotsna (2019). Strategic Management of Universal Technologies for Redefining Productivity \& Performance. International Journal of Applied Engineering and Management Letters (IJAEML), 3(2), 81-95.

[78] Aithal, P. S. (2016). Innovations in student centric learning-A study of top business schools in India. International Journal of Engineering Research and Modern Education (IJERME), 1(1), 298-306.

[79] Aithal, P. S. (2016). Innovations in experimental learning-A study of world top business schools. International Journal of Scientific Research and Modern Education (IJSRME), 1(1), 360375 .

$* * * * * * * * * * *$ 